\title{
Role and activity of jasmonates in plants under in vitro conditions
}

\author{
Monika Kamińska ${ }^{1}$
}

Received: 5 January 2021 / Accepted: 23 April 2021 / Published online: 6 May 2021

(c) The Author(s) 2021

\begin{abstract}
Jasmonates (JAs), such as jasmonic acid and its methyl ester, are lipid-derived compounds with signal functions in plant growth and development, as well as in responses to stress. JAs are widely distributed in plants as natural plant growth regulators. JAs do not work independently but work as a part of a complex signaling network with other phytohormones. They are deployed to induce response during wounding and are often used for elicitation and stimulation of secondary metabolites production in different in vitro culture systems. Application of JAs seems to be promising during different steps of the micropropagation system for different species. JAs stimulate proliferation rate of shoots, roots, callus and induce microtubers and bulblets formation. However, negative effects of JAs on the condition of plant tissues are also reported, e.g. leaf senescence, reduced growth and inhibited somatic embryogenesis. This review summarizes the current knowledge of the application and properties of jasmonates under in vitro conditions in terms of cell division, explant growth, proliferation ability, storage organ formation and stress response.
\end{abstract}

\section{Key message}

The review summarized in detail the results achieved for plants cultivated in vitro in the presence of jasmonates and their possible mechanisms of action.

Keywords Cell proliferation $\cdot$ Micropropagation $\cdot$ Somatic embryogenesis $\cdot$ Storage organ formation $\cdot$ Abiotic stress

\section{Introduction}

Jasmonates (JAs) are widely distributed in plant tissues with high activity and growth rate, such as the stem tips, root tips, young leaves, flowers and unripe fruits. Endogenous JAs levels increase in response to the external stimuli, including mechanical damage, pathogen attack and osmotic stress (Sembdner and Parthier 1993; Creelman and Mullet 1995).

Jasmonic acid (JA) and its methyl ester (methyl jasmonates, MeJA) are linolenic acid (LA)-derived cyclopentanone-based compounds that belong to oxylipins (Creelman and Mullet 1995). It is believed that JA and MeJA represent a separate group of plant growth regulators with hormone-like

Communicated by Mohammad Faisal.

Monika Kamińska

mkaminska@biol.uw.edu.pl

1 Department of Plant Biochemistry, Faculty of Biology, University of Warsaw, 1 Miecznikowa Street, 02-096 Warsaw, Poland properties (Sembdner et al. 1990). The initiation of JAs biosynthesis begins with the release of $\alpha$-linolenic acid (Fig. 1) from chloroplast membranes, which undergoes multistage reactions catalyzed by enzymes present in plastids, peroxisomes and cytoplasm (Ghasemi Pirbalouti et al. 2014; Sharma and Laxmi 2016) and is regulated by light conditions (Zhai et al. 2007). Among exogenous JAs it was showed that more effective is MeJA due to its easier cell membrane crossing ability in comparison to JA and quick demethylation to free JA (Fattorini et al. 2018).

Bioactive form of JAs synthesized by JAR1 (JasmonylL-amino acid synthetase; Fig. 1) is (7S,3R)-JA-Ile perceived by the COI1 receptor (the F-box protein CORONATINE INSENSITIVE 1) (Staswick and Tiryaki 2004; Fonseca et al. 2009; Wasternack and Hause 2013; Ueda et al. 2020). However, biochemical analysis indicated that OSJARI encodes an enzyme conjugating JA not only to isoleucine (Ile) but also to tryptophane (Trp), leucine (Leu), methionine (Met), phenylalanine (Phe) and valine (Val) (Staswick 2009). JAIle binds to the Skp1-Cullin-F-box $(\mathrm{SCF})^{\mathrm{COI} 1}$ E3 ubiquitin ligase complex which further recruits JAZ (JASMONATE 
Fig. 1 Schematic representation of JA biosynthesis, conversion to the biologically active JA-Ile by JAR 1 and interactions between JA and GA signaling pathways. In the absence of JA (a) repressors JAZ bind and inhibit the MYC family of transcription factors. JA-Ile binds to the $\mathrm{SCF}^{\mathrm{COI} 1}$ ubiquitin ligase complex and promotes degradation of JAZs, thus releasing MYC2 to trigger expression of JA-responsive genes. GA pathway is mediated through DELLA proteins. Without GA (b) DELLAs compete with MYC2 for binding to JAZs enabling expression of MYC2regulated genes. In the presence of GA repressors DELLA are degraded through $\mathrm{SCF}^{\mathrm{GID} 2}$ complex, releasing JAZ to bind MYC2

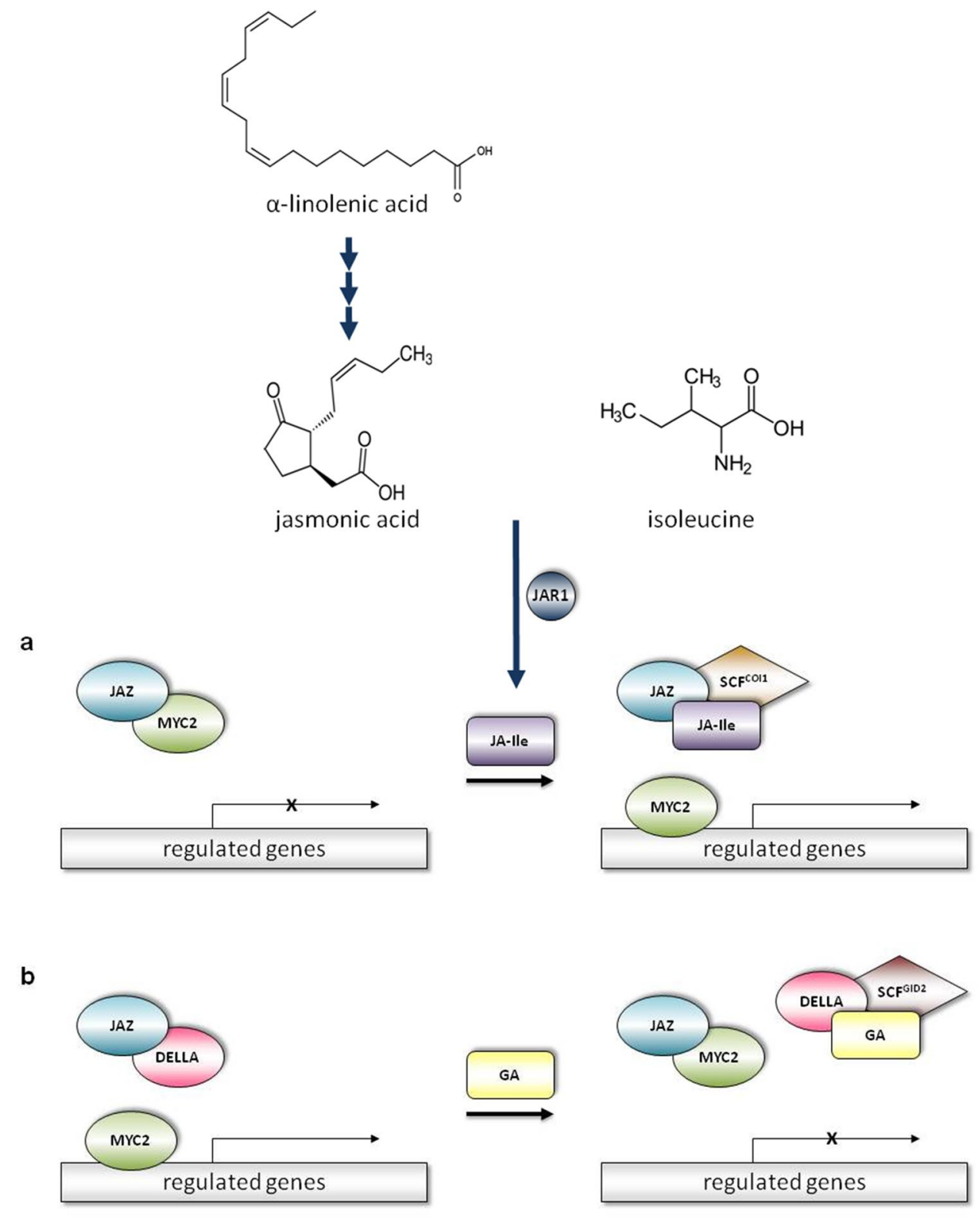

ZIM-DOMAIN) transcriptional repressors for degradation through $26 \mathrm{~S}$ proteasome, allowing the expression of JAresponsive genes (Zhai et al. 2017; Hyde et al. 2018; Fig. 1). JAZ repressors bind and inhibit the MYC family of transcription factors which ultimately leads to the growth promotion of leaves. However, JAZ-MYC interaction also takes part in plant growth inhibition during defense responses (Major et al. 2017; Guo et al. 2018). JA-Trp acts as an endogenous auxin inhibitor in $A$. thaliana and exogenously caused agravitropic root growth (Staswick 2009). The biological functions of other JA-amino acid conjugates are still unclear, although different COI1 homologs with variable preference perceive those bioactive molecules (Xiao et al. 2014; Yan et al. 2016).
The presence of JAs is associated with different changes in plant development and structure. Many studies have shown that JA and MeJA are involved in leaf senescence by stimulation of chlorophyll degradation. JA exposure causes damage to chloroplasts, decreases photosynthetic activity as a result of stimulation of RuBisCO degradation, stimulates destruction of cell membrane structure in the lipid peroxidation process and increases expression of senescence associated genes. The application of MeJA in turn, leads to an increase in the rate of cellular respiration, proteolytic and peroxidase activity in the leaves (Parthier 1990; Creelman and Mullet 1997; Liu et al. 2016). However, JAs are also involved in the defense responses to herbivore attack, promotion of shoot growth, storage organ formation: bulblets 
and tubers, flowering processes, fruit and inflorescence number (Rohwer and Erwin 2008; Hummel et al. 2009).

Many studies on JAs effect were carried out on field or pot-grown plants, while its potential in in vitro culture need to be fully understood. The aim of this review is to summarize studies investigating the role of jasmonates in micropropagation, explants growth, storage organ formation and somatic embryogenesis in plants under in vitro conditions. This review might provide a starting point for further research using jasmonates.

\section{Use of JAs during plant micropropagation}

Basal culture medium provides all nutrients, energy and water necessary for plantlets, organs, tissues or cells growth. Regulation of developmental processes in plant tissue culture generally requires the addition of plant growth regulators (PGRs). Successful micropropagation strictly depends on a selection of appropriate PGRs and their concentration. The most commonly used PGRs are auxins and cytokinins which regulate growth and organize development of a plant tissue. In general, auxin mediates cell division and cytokinin mediates cell differentiation (Moubayidin et al. 2009). However, cultured plant tissues are also influenced by gibberellins (GAs), brassinosteroids (BRs), ethylene (ET), abscisic acid (ABA), salicylic acid (SA), jasmonates (JAs) and interactions among them (Gaspar et al. 1996; Phillips and Garda 2019). Exogenous application of JAs can affect a great variety of morphological and physiological responses in plants. Jasmonates, like all growth regulators, do not work independently but they are involved in a complex signaling network of interactions among multiple plant hormone signaling pathways (Yang et al. 2019). Different effects of exogenously applied PGRs, including JAs, may arise from modification of synthesis, catabolism, activation, sequestration, transport, or sensitivity to endogenous phytohormones of the same or other type (Gaspar et al. 1996).

A large number of studies conducted in different in vitro conditions have shown that exogenous JAs inhibit plant growth by suppression of the cell proliferation and expansion (Patil et al. 2014). However, high level of endogenous JAs was observed especially in young organs with high rate of cell division, therefore growth-promoting activity of JAs cannot be excluded and it was proposed that JAs-mediated physiological response might be a consequence of changes in endogenous cytokinins level which affects and regulates cell cycle (Avalbaev et al. 2016). Cell cycle is also under the gibberellins signaling control (Achard et al. 2009). Analysis of Nicotiana attenuata plants treated with exogenous JA and GA showed that JAs might indirectly repress shoot growth by antagonizing the GA pathway through specific DELLAJAZ interactions and down regulation of photosynthesis
(Machado et al. 2017). The GA signal is perceived by GID1 (GA-insensitive dwarf1). The GID1-GA complex stimulates plant growth and development by down-regulating DELLA repressors. In the absence of GA DELLAs compete with MYC2 for binding to JAZs, thereby releasing MYC2 to activate expression of MYC2-regulated genes. In the presence of GA DELLAs are degraded through $\mathrm{SCF}^{\mathrm{GID} 2} \mathrm{E} 3$ complex leading to inhibitory JAZ-MYC2 interactions (Fig. 1; De Bruyne et al. 2014).

\section{Cell cycle and cell proliferation}

One of the first characterized physiological ex vivo effect of JAs was growth inhibition of the potted Vicia faba pericarp as a result of a cell cycle disturbance (Dathe et al. 1981). On this basis, a number of studies focused on the inhibitory effect of JAs on plant growth have been developed also under in vitro conditions. Ueda and Kato (1982) reported that JA and MeJA were powerful inhibitors of kinetinand N-phenyl-N'-(2-chloro-4-pyridyl)urea-induced callus growth of Glycine max. Plant growth and development are related to cell expansion and cell differentiation, but also are strictly linked with cell division (Perrot-Rechenmann 2010). Światek et al. (2002) compared the effect of JA with ABA on the cell cycle using Nicotiana tabacum BY-2 cell line. Their results showed that these phytohormones disturbed cell cycle progression by preventing DNA replication. Exogenous application of both compounds before the G1/S transition caused retention of cells in the G1 phase of the cell cycle. ABA application at a later stages did not affect further progression of the cell cycle, whereas JA effectively prevented cells from entering mitosis (cells arrested in G2 phase; Fig. 2). Those observations showed that the growth inhibition in response to JA might not resulted from a cell expansion in the elongation zone, but from a disruption of meristem activity (Świątek et al. 2002). Continued research confirmed that JA application led to tobacco BY-2 cell arrest in both G1 and G2 phases (Świątek et al. 2004). Analysis of a gene expression of Arabidopsis genome showed that also MeJA inhibited the activation of the $\mathrm{M}$ phase genes thus cells were arrested in the G2 phase of the cell cycle (Pauwels et al. 2008; Fig. 2). However, JAs treatment leads to reprogramming cells through the activity of specific transcription factors and proteins activity. It was indicated that MeJA primarily activates expression of the genes involved in jasmonate synthesis, thus cell cycle genes expression is suppressed in the later stages (Gumerova et al. 2015; Pauwels et al. 2008).

In asynchronously dividing Taxus cuspidata cultures addition of MeJA resulted in turn in four effects on the cell cycle: transient increase in G2 phase cells, transient decrease in S phase cells, and at later stages post-elicitation, increase in G0/G1 phase cells and decrease in G2 and S phase cells. 
After $96 \mathrm{~h}$ of elicitation with MeJA, percentage of cells in the $\mathrm{G} 2$ and $\mathrm{S}$ phases decreased but in the G1/G0 phases increased, therefore it was suggested that cells treated with MeJA were not arrested in the G2/M transition but progression through the cell cycle was slowed down. A time lag between MeJA-mediated growth inhibition and cell death in asynchronously dividing T. cuspidate cell culture suggested that observed growth suppression in response to MeJA was not due to necrosis and/or rupturing of cell membranes, although the evidence indicated that JAs might affect cell walls (Capitani et al. 2005; Patil et al. 2014). Northern analysis and in situ hybridization using cDNA probes of the G1/S phase-specific genes confirmed enhanced proliferation growth of $N$. tabacum cells in response to relatively low concentrations of MeJA, whereas in highest concentration $(10 \mu \mathrm{M})$ MeJA indicated transient effect and was more effective in enhancing defense-related processes such as cell wall thickening (Capitani et al. 2005). It was reported that MeJA elicitation increases content of cellular monolignols in A. thaliana (Pauwels et al. 2008) which polymerize into lignin according to the cell-wall class III peroxidases generating reactive oxygen species (ROS) from hydrogen peroxide. Peroxidase expression and activity is also stimulated by JA. These changes in response to JA are associated with a cessation of a growth and decreased cell expansion as a result of increased cross-linking of primary cell-wall components (Almagro et al. 2009; Napoleao et al. 2017; Hyde et al. 2018). An earlier report indicated that JAs delayed

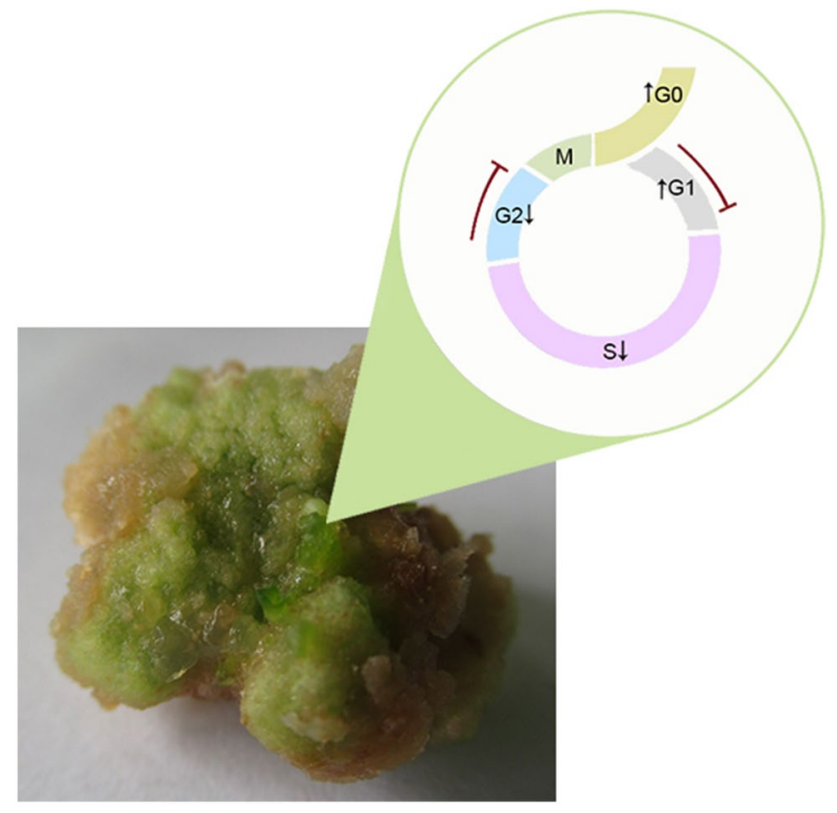

Fig. 2 Main effects of exogenous JAs on the cell cycle. JAs might cause retention of cells in the G1 and G2 phases, increase number of cells arrested in the G0 and G1 phases, and decrease number of cells entering the $\mathrm{S}$ and $\mathrm{G} 2$ phases regeneration of the cell wall in protoplast of Solanum tuberosum (Ravnikar et al. 1992). In contrary to all these observations, it was reported that JA promotes division of mitotically less active cells in the root apical meristem named quiescent center (QC) in A. thaliana. Furthermore, JA pre-treatment increased number of new columella cell layer between QC and ablated cells, which suggest that JA stimulates stem cell replacement after ablation (Chen et al. 2011). JA-dependent regeneration network is highly important for plant response to parasitic infection (Zhou et al. 2019).

Effect of JAs on the cell division was also indirectly visualized during callus propagation under in vitro conditions. In higher concentration $(5-50 \mu \mathrm{M})$ both JA and MeJA inhibited callus growth of Medicago sativa during differentiation stage (Ruduś et al. 2001; Table 1; Fig. 3). Elicitation with 10-100 $\mu \mathrm{M}$ MeJA significantly decreased cell viability of $T$. cuspidata and Taxus baccata suspension culture on $\mathrm{W}_{\mathrm{B} / \mathrm{A}}$ medium supplemented with 6-benzylaminopurine (BA) and 1-naphthaleneacetic acid (NAA) (Bulgakov et al. 2011). Also $100 \mu \mathrm{M}$ MeJA significantly decreased cell viability in protoplast culture of $A$. thaliana due to the rapid accumulation of $\mathrm{H}_{2} \mathrm{O}_{2}$ (Zhang and Xing 2008). Enhanced hydrogen peroxide and superoxide radical production was also detected in Salvia miltiorrhiza hairy roots (Liang et al. 2012) and Panax ginseng roots (Ali et al. 2006). In Ricinus communis gradual accumulation of $\mathrm{H}_{2} \mathrm{O}_{2}$ was indicated between 1 and $6 \mathrm{~h}$ after MeJA treatment of plants germinated under ex vivo conditions (Soares et al. 2010). High level of accumulated ROS leads to lipid peroxidation in cell membranes that might cause membrane damages, imbalance of cell homeostasis and further cell death (Pérez-Pérez et al. 2012). Correlation between oxidative stress and JAs is very complex. It was proposed that JA at a definite concentration can directly modify superoxide dismutase (SOD) structure that stimulates its activity (Maksymiec and Krupa 2006), thus JAs indicated both antioxidative and pro-oxidative activity (Ho et al. 2020). Exposure to JA and MeJA (50-200 $\mu \mathrm{M}$ ) of Mentha $\times$ piperita cell suspension culture resulted in a less biomass accumulation than that of the control. Both elicitors suppressed growth of the cell suspension culture, although stronger inhibition was noted for MeJA application. Furthermore elicitation resulted in cultures color change from greenish to brown. Authors mentioned that this effect might be caused by increased accumulation of phenolic compounds and their oxidation what correlates with stimulatory effect of JAs on secondary metabolites accumulation (Krzyzanowska et al. 2011).

Earlier reports indicated that JAs not only have suppressing effect, but also have stimulating effect on cell division in various culture conditions or plant species, thus effect of JAs depends on its concentration, interaction with a specific PGRs and type of explant. In S. tuberosum JA $(0.01-1.0 \mu \mathrm{M})$ 


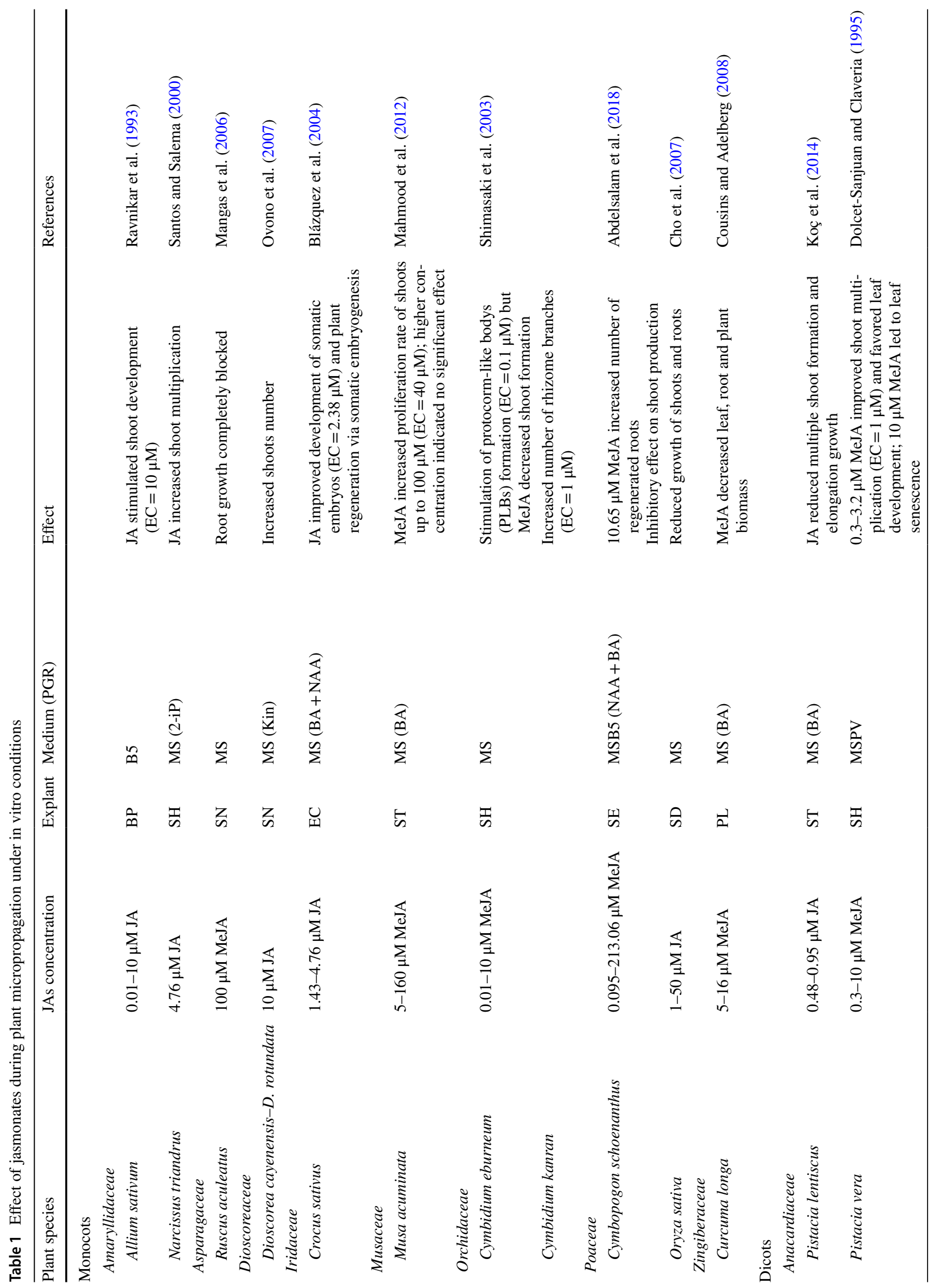




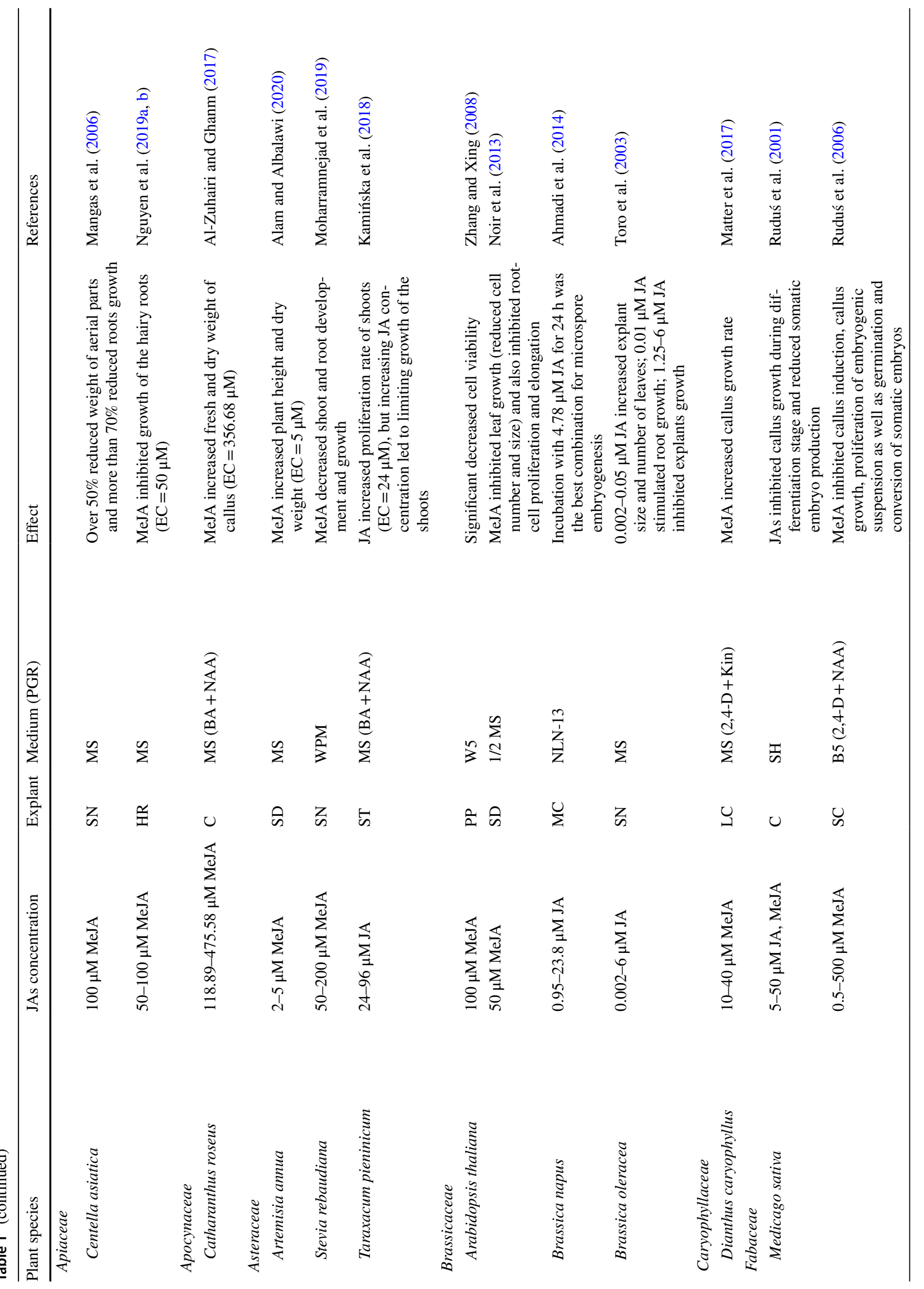




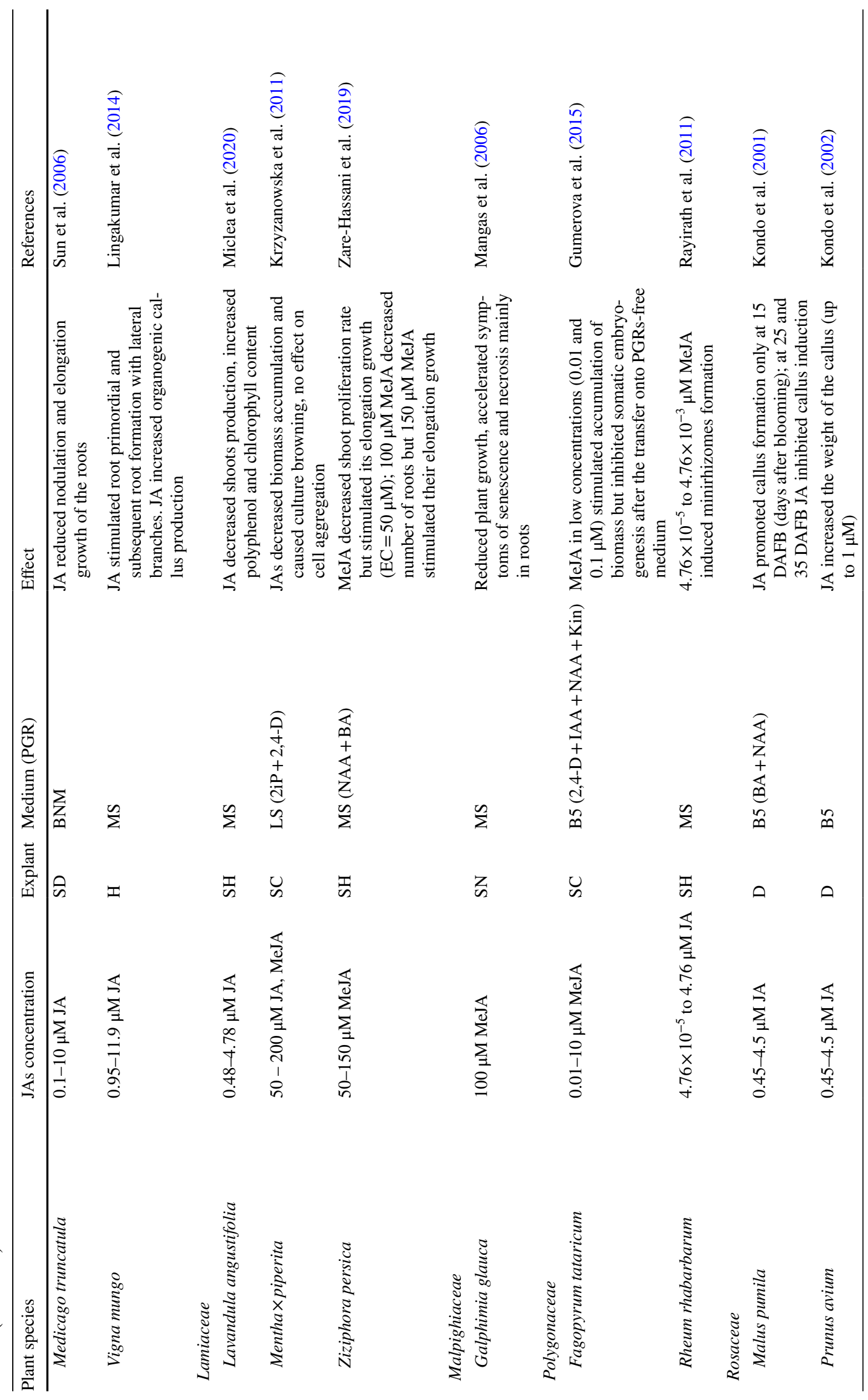




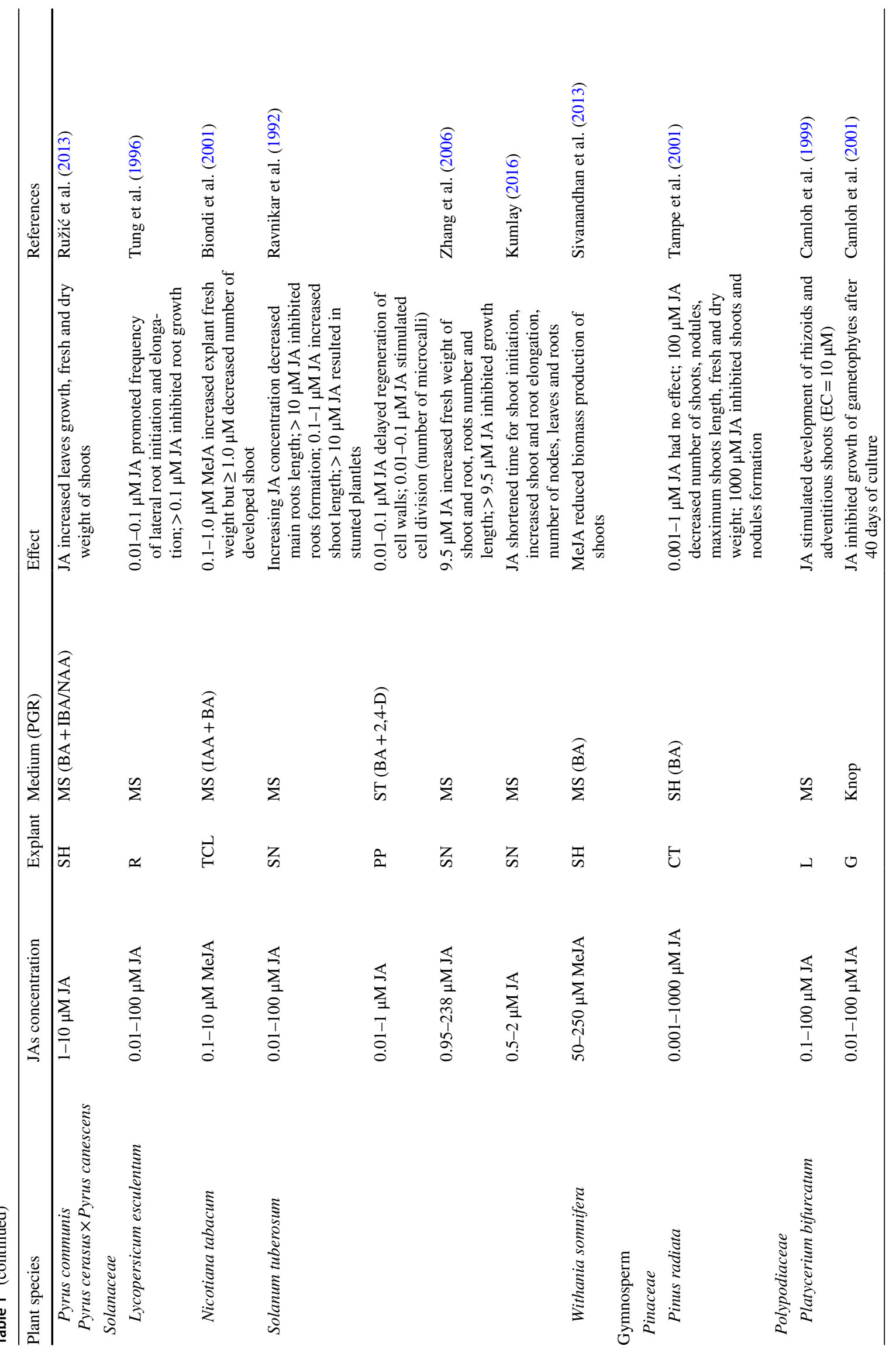


combined with BA and 2,4-dichlorophenoxyacetic acid (2,4D) stimulated cell division manifested by increased number of microcalli (Ravnikar et al. 1992). Similar results were obtained for Prunus avium and Vigna mungo callus cultures propagated on B5 and MS medium, respectively, supplemented with JA in the comparable concentrations (Table 1), although without any other hormonal additives (Kondo et al. 2002; Lingakumar et al. 2014). Addition of the ester derivative of JA also affected callus growth. MeJA $(10-40 \mu \mathrm{M})$ combined with 2,4-D and kinetin (Kin) increased callus growth rate from Dianthus caryophyllus leaf explants (Matter et al. 2017). Even ten times higher concentration $(118.9-475.6 \mu \mathrm{M})$ of MeJA in MS medium with BA and NAA increased fresh and dry weight of Catharanthus roseus callus (Al-Zuhairi and Ghanm 2017). The JAs effect might also depend on the growth stage of the plants. In Malus pumila growing in an open field, the endogenous level of JA is high in the early stages of pulp development, thus effect of exogenous JA under in vitro conditions varied between samples from ex vivo plants collected in different days after blooming (DAFB). It was indicated that only at 15 DAFB, when the plant tissue was still in the cell division stage, JA promoted callus formation. At 25 and 35 DAFB, JA in turn inhibited callus formation probably because endogenous JA concentrations increase with time of fruit growth. These results indicated that only low endogenous JA level promotes callus formation, whereas increasing JA concentration inhibits this process (Kondo et al. 2001).

\section{Organogenesis}

Analyzing JAs addition during plant micropropagation, it was reported that these compounds perform varied effects, either promoting or inhibitory. For example, JA in concentrations of $0.5-2.0 \mu \mathrm{M}$ shortened time for shoot initiation, increased shoot and root elongation, number of nodes, leaves and roots in stem nodes of $S$. tuberosum placed onto MS medium (Kumlay 2016; Table 1). In turn, growth of the Oryza sativa seedling was inhibited with increasing concentration of JA in MS medium, even in the presence of $1 \mu \mathrm{M}$ JA root growth was reduced twofold over the control (Cho et al. 2007). As it was noticed role of JAs seems to be species- and context-dependent (Lakehal and Bellini 2018) and mentioned JA and GA growth-defense balance should be considered during analyzing the JAs effect on the propagation effectiveness. Generally it is presupposed that JA prioritizes defense, in turn GA-prioritizes growth. Inhibited plant growth as a results of JA treatment is probably related with suppression of GA-mediated pathway (Hou et al. 2013; Nguyen et al. 2019a). It was indicated that MeJA-mediated growth inhibition might results also from the perturbations in mitochondrial membrane integrity, decreases in the 


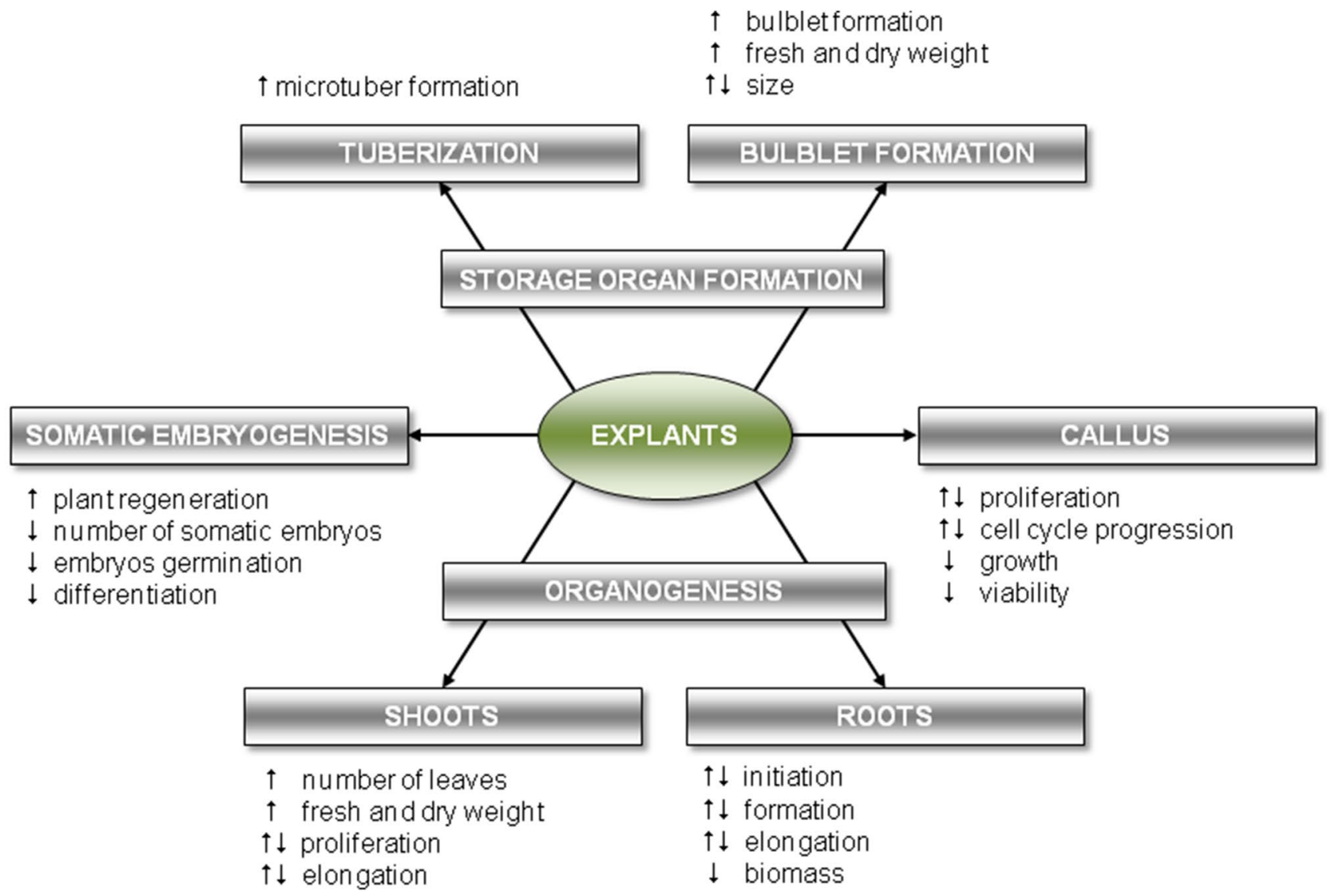

Fig. 3 Diagrammatic representation of the effects of exogenously applied JAs under in vitro conditions (promoting and inhibitory effects)

biosynthesis of ATP and proteins involved in energy metabolism (Ruiz-May et al. 2011; Cho et al. 2007).

\section{Shoots proliferation and growth of the aerial parts}

In the shoot induction, development and proliferation cytokinins play a vital role. In S. tuberosum stem node cultures it was indicated that exogenous JA increased the ratio between physiologically active and inactive cytokinins without changing its total content (Dermastia et al. 1994). In turn, Triticum aestivum seedlings treated with MeJA showed twofold increased accumulation of cytokinins without changes in ABA and auxins levels (Avalbaev et al. 2016). It was also reported that MeJA increased accumulation of cytokinins, despite the antagonistic interaction between JA and cytokinin noted in xylem development of A. thaliana (Jang et al. 2017). JAs were considered as inhibitors of cytokinininduced plant growth manifested by reduced biomass in $A$. thaliana (Yan et al. 2007,2009; Zhang and Turner 2008; Noir et al. 2013; Attaran et al. 2014; Table 1; Fig. 3) and in O. sativa (Yang et al. 2012; Hibara et al. 2016). JA suppresses cell proliferation in wounded $A$. thaliana plants leading to a reduced leaf size with fewer and smaller epidermal cells giving a "bonsai effect" (Zhang and Turner 2008; Noir et al. 2013; Yang et al. 2019). JAs act as a growth inhibitors even in combination with exogenous BA. Repressed growth of the shoots was observed for Pinus radiata (Tampe et al. 2001), Curcuma longa (Cousins and Adelberg 2008) and Withania somnifera (Sivanandhan et al. 2013). No shoot production was observed for Lavandula angustifolia treated with $4.78 \mu \mathrm{M} \mathrm{JA}$ (Miclea et al. 2020). Addition of JA even in concentrations lower than $1 \mu \mathrm{M}$ into MS medium with BA reduced multiple formation and elongation of Pistacia lentiscus shoots (Koç et al. 2014). JA in concentrations up to $0.05 \mu \mathrm{M}$ increased dry weight of shoots, leaves and roots developed from single nodes explants and number of leaves of Brassica oleracea cultivated in MS medium. In higher concentrations (1.25-6. $\mu \mathrm{M}) \mathrm{JA}$ inhibited explant growth (Toro et al. 2003). MeJA in concentrations $0.1-1.0 \mu \mathrm{M}$ also increased explant fresh weight but in higher concentration decreased number of developed shoots in N. tabacum cultured on MS medium supplemented with BA and IAA. Histological analyzes indicated that loss of the thin layer tobacco explants ability to regenerate in response to MeJA treatment was due to a strong hypertrophy of the cells and 
disappearance of meristemoids (Biondi et al. 2001) and reduced shoot primordial development (Capitani et al. 2005).

For various species JA stimulated shoot proliferation rate and growth when it was added into a medium in concentrations up to $10 \mu \mathrm{M}$ (Table 1). JA supplementation of a medium containing N6-(2-Isopentenyl)adenine (2-iP) increased shoot multiplication and development in Allium sativum (0.1-10 $\mu \mathrm{M} \mathrm{JA})$ and Narcissus triandrus $(4.8 \mu \mathrm{M}$ JA) (Ravnikar et al. 1993; Santos and Salema 2000). Combined with Kin, $10 \mu \mathrm{M}$ JA increased shoot number of Dioscorea cayenensis - D. rotundata (Ovono et al. 2007). In Pyrus communis and $P$. cerasus $\times P$. canescens shoots addition of 1-10 $\mu \mathrm{M} \mathrm{JA}$ into MS medium supplemented with BA and IBA or NAA increased leaf growth, fresh and dry weight of shoots (Ružić et al. 2013). MeJA (0.3-3.2 $\mu \mathrm{M}$ ) also improved shoot multiplication and favored leaf development of Pistacia vera propagated onto MSPV medium containing BA and IBA, although $10 \mu \mathrm{M}$ MeJA led to the leaf senescence and decreased shoot proliferation (DolcetSanjuan and Claveria 1995). On the other hand in Musa acuminata increasing concentration of MeJA up to $100 \mu \mathrm{M}$ also stimulated proliferation rate of shoots in presence of BA (Mahmood et al. 2012). Similarly proliferation rate of Taraxacum pieninicum shoots on MS medium supplemented with BA and NAA was stimulated by JA in higher concentrations (24-96 $\mu \mathrm{M})$. However, it was reported that increasing concentration of JA limited the growth of the obtained shoots (Kamińska et al. 2018). The opposite effect was obtained for Ziziphora persica multiplied shoots on MS medium supplemented with the same PGRs, where MeJA decreased shoot proliferation rate but stimulated its elongation (Zare-Hassani et al. 2019). Increased height and dry weight of the seedlings probably by a rapid and significant increase of cytokinins level was observed also for T. aestivum and Artemisia annua treated with only MeJA in low concentrations (0.01-1 $\mu \mathrm{M}$ and 2-5 $\mu \mathrm{M}$, respectively) (Avalbaev et al. 2016; Alam and Albalawi 2020), but high MeJA concentrations (10 and $100 \mu \mathrm{M}$ ) inhibited wheat seedlings growth (Avalbaev et al. 2016). Reduced growth of the shoots in response to JA or MeJA alone in MS medium was also reported in S. tuberosum (Ravnikar et al. 1992), O. sativa (Cho et al. 2007), Centella asiatica and Galphimia glauca (Mangas et al. 2006). In A. thaliana inhibited leaf growth as a result of treatment with $50 \mu \mathrm{M}$ MeJA was manifested by both cell number and cell size reduction (Noir et al. 2013). Furthermore, it was indicated that exogenous MeJA suppresses hypocotyl elongation in a $\mathrm{SCF}{ }^{\mathrm{COI}}$-dependent pathway in Arabidopsis under various light conditions, particularly effectively under red light (Chen et al. 2013). Signal cross-talk between JA and the red-light receptor phytochrome B (phyB) is thought to intermediate growth stimulation in neighboring plants competing for light. However, in further research it was shown that growth restriction at high level of endogenous
JA was independent of phyB but involved dysregulation of Trp biosynthesis (Major et al. 2020).

\section{Rooting of the plantlets}

The most important PGRs during rooting process of in vitro derived shoots are auxins, especially indole-3-butyric acid (IBA) and indole-3-acetic acid (IAA) (Goel et al. 2018). Increased accumulation of endogenous JA might be stimulated during adventitious root (AR) formation by conversion of the IBA to IAA in NO-mediated upregulation of JA biosynthetic genes (Fattorini et al. 2017). It was suggested that MeJA acts during dedifferentiation phase by increasing sensitivity to auxin of the founder cells which divide and the descendent cells become increasingly determined to root formation under the auxin signal (De Klerk 2002). However, it was documented that JA and auxins antagonize root growth through interaction between JAZ protein and transcription factor MYC2 (Yang et al. 2019; Fig. 1). Furthermore, MeJA induced root growth inhibition through the reduction of Arabidopsis root cell length with involvement of COII in this process (Adams and Turner 2010). These results suggest that JAs modulates root formation via whole JAs pathway COI1-JAZs-MYC2 (Chini et al. 2009), but it was also reported that JA inhibits auxin-induced lateral root (LR) formation independently of the COI1 receptor (Ishimaru et al. 2018). Inhibition of AR initiation induced by JAs involve cytokinin-dependent pathway in A. thaliana (Lakehal et al. 2020). In turn auxin increases JA conjugation efficiency lowering free JA level. This auxin-JA interaction supports the hypothesis that JA signaling pathway negatively regulates AR in Arabidopsis hypocotyls (Gutierrez et al. 2012). Other studies indicated that JAs inhibits primary root (PR) elongation but promotes LR formation (Lakehal and Bellini 2018) and it was reported that IAA biosynthesis is required for MeJA to promote LR formation (Sun et al. 2009; Cai et al. 2014). Furthermore, it was shown that JA affect PR and LR growth by an auxin-independent pathway. The inhibiting effect of JA on a root system was found to be caused by a reduced cortex cell length and the low rate of the root-meristem cell formation in Helianthus annuus seedlings (Monzón et al. 2012). It was also suggested that the effect of JAs on the root growth may result from the reorganization of the root meristem, decreased cell division, inhibited cell elongation and premature cell maturation (Xue and Zhang 2007; Tung et al. 1996).

As for all micropropagation steps concentration of PGR does matter, but for some species, e.g. O. sativa, JA regardless of its concentration reduced root growth (Cho et al. 2007). In Medicago truncatula in turn only $0.1-10 \mu \mathrm{M} \mathrm{JA}$ inhibited nodulation and suppressed roots elongation growth (Sun et al. 2006). Similarly MeJA (5-16 $\mu$ M) decreased root biomass in Curcuma longa plantlets (Cousins and Adelberg 
2008). However, suppressed rooting process was mainly associated with the high concentrations of JAs (Table 1). Addition of $100 \mu \mathrm{M}$ MeJA into MS medium reduced roots growth of C. asiatica, Ruscus aculeatus and G. glauca (Mangas et al. 2006). Furthermore, MeJA (50-100 $\mu \mathrm{M})$ inhibited hairy roots growth of $C$. asiatica (Nguyen et al. 2019b). Supplementation of WPM medium with MeJA in concentrations of 50-200 $\mu \mathrm{M}$ led to decreased roots and shoots development and growth on nodal explants of Stevia rebaudiana (Moharramnejad et al. 2019). In turn in Z. persica $100 \mu \mathrm{M}$ MeJA decreased number of roots, although at higher concentration $(150 \mu \mathrm{M})$ stimulated root elongation (Zare-Hassani et al. 2019). Stimulation of root formation by JAs was also noted for low concentrations (up to $1.0 \mu \mathrm{M}$ ) in S. tuberosum, B. oleracea and Lycopersicum esculentum (Ravnikar et al. 1992; Tung et al. 1996; Toro et al. 2003; Zhang et al. 2006; Table 1). In Cymbidium kanran $1 \mu \mathrm{M}$ JA increased number of rhizome branches (Shimasaki et al. 2003). Even in lower concentrations $\left(4.76 \times 10^{-5}\right.$ to $\left.4.76 \times 10^{-3} \mu \mathrm{M}\right) \mathrm{JA}$ induced minirhizomes formation in shoot clusters of Rheum rhabarbarum (Rayirath et al. 2011). JA also stimulated root primordium and subsequent root formation with lateral branches in $V$. mungo hypocotyls placed onto MS medium (Lingakumar et al. 2014). Addition of $10.65 \mu \mathrm{M}$ MeJA into MS medium supplemented with Gamborg's B5 vitamins, BA and NAA increased number of regenerated roots in Cymbopogon schoenanthus seedlings but showed negative effect on a shoot production (Abdelsalam et al. 2018).

It was indicated that JA derived by the demethylation of MeJA, applied at $0.01 \mu \mathrm{M}$ in combination with IBA and Kin enhanced AR in N. tabacum and A. thaliana seedlings and thin cell layers (TCLs) under dark conditions. The endogenous IAA levels increased in the TCLs at the time of the first AR-cell cluster formation under MeJA treatment. Furthermore, it was shown that also xylogenesis in Arabidopsis TCLs is under the JAs control. Role of JAs in these processes was related to crosstalk between JA- and ET-signalling (Fattorini et al. 2009, 2018). It was proposed that JA at high concentrations promote xylogenesis rather than AR formation, and mentioned cross-talk between JA and ET may decide which of these competing processes will occur (Druege et al. 2019). These results were confirmed by Betti et al. (2019) who showed that during AR formation in Arabidopsis stem explants cultured with IBA the antagonism between JA and ET is based on an involvement of the EIN2 (Ethylene Insensitive2) and COI1 cross-talk. It was also assumed that JAs cooperate with cytokinins to repress initiation of AR formation in Arabidopsis under constant red light conditions thus JAs effect on AR formation might also depend on light conditions during culture (Lakehal et al. 2020; Fig. 3).

\section{Somatic embryogenesis}

Somatic embryogenesis (SE) is the developmental process in which a competent cell or a cell group undergoes biochemical and molecular changes resulting in the formation of a somatic embryo (Yang and Zhang 2010). Somatic embryos are bipolar structures with an apical pole (the future shoot) and a basal pole (the future root), both with its own meristem (Horstman et al. 2017). This regeneration system is preferred over organogenesis due to a low frequency of chimeras, a high number of regenerants and a limited level of somatic variation (Gaj 2001; Carra et al. 2019). One of the determining factors during induction of SE is IAA metabolism in the cells. Acquisition the embryogenic potential by pro-embryogenic mass is dependent on auxin homeostasis at a specific level (Nic-Can and LoyolaVargas 2016). In Arabidopsis SE is a two-step process. In the first step early cotyledonary zygotic embryos are placed on medium supplemented with auxins to stimulate formation of the embryogenic tissue. In the next step formation of the somatic embryos is stimulated by the removal of auxins from the medium. JA is a key component of embryogenesis regulation in the pathway including phytoglobin 2 (PGB2), NO and several JA-responsive intermediates (Bassuner et al. 2007; Mira et al. 2016). It was suggested that JAs inhibit embryo germination in angiosperm (Białecka and Kępczyński 2003), although high endogenous level of JA is essential for somatic embryo formation in M. sativa. A relatively high and stable JA content was reported in somatic embryos developed from globular through torpedo till earlycotyledonary stage (Ruduś et al. 2009). Exogenous MeJA not only inhibited callus growth of this species during differentiation stage, but also negatively affected the proliferation of embryogenic suspension and reduced somatic embryos production (Ruduś et al. 2001, 2006; Table 1; Fig. 3). Tokuji et al. (1995) showed that MeJA markedly delayed somatic embryo differentiation from cell clusters to torpedo stage and repressed their further regeneration in Daucus carota. Cells of Fagopyrum tataricum from suspension culture after MeJA treatment were almost completely unable to produce somatic embryos. Proposed explanation was based on possible suppression of the cell cycle genes expression and cells arrest of entry into mitosis. On the other hand it cannot be excluded that exogenous MeJA induced perturbations in the level of endogenous hormones which after cells transfer onto hormone-free medium prevent activation of the embryogenesis process (Gumerova et al. 2015). In contrast to these results, Reinbothe et al. (1994) indicated that MeJA induces embryogenesis-related proteins and mRNA in Nicotiana plumbaginifolia. Improved microspore embryogenesis was obtained for Brassica napus treated with $4.8 \mu \mathrm{M} \mathrm{JA}$ for $24 \mathrm{~h}$. At higher level $(9.5$ and $23.8 \mu \mathrm{M}) \mathrm{JA}$ improved embryogenesis and callogenesis only after $6 \mathrm{~h}$ incubation. 
Longer incubation decreased microspore embryogenesis and microspore-derived embryos germination (Ahmadi et al. 2014). Blázquez et al. (2004) indicated that JA also in low concentration $(2.4 \mu \mathrm{M})$ significantly improved SE and plant regeneration in Crocus sativus. Equivalent to somatic embryos in orchids, protocorm-like bodies (PLBs) formation was improved as a result of a MeJA treatment, although PLBs formation decreased as MeJA level increased (Teixeira da Silva 2012). Similar results were obtained in shoots culture of Cymbidium eburneum where addition of MeJA into MS medium stimulated PLBs formation with simultaneous decreased shoot formation (Shimasaki et al. 2003).

\section{Microtuber and bulblet formation}

For some species culture through bulblets or microtubers has become a more effective method of propagation due to the genetic purity (Wang and Hu 1982; Sultana et al. 2010). Formation of this both storage organs under in vitro conditions might be affected by several factors such as sucrose levels, photoperiods and PGRs and is controlled by biochemical and genetic factors (Gheisari and Miri 2017; Islam et al. 2017).

Several phytohormones are associated with the processes associated with the tuberization. Especially significant role was assigned to $\mathrm{GA}_{3}$ which regulates the change in cell growth orientation from longitudinal to radial swelling of the stolon tip what is characteristic step during tuber formation (Hannapel et al. 2017). JAs also induce changes of the cell division marked by cortical microtubules reorientation and radial expansion direction during initiation of storage organs formation (Shibaoka 1991; Matsuki et al. 1992; Podwyszyńska et al. 2015). JAs involvement in this process was repeatedly confirmed not only in tuber formation from stolon apex in plants from soil cultivation (Koda 1997; Cenzano et al. 2003) but also during further cell expansion of medullary tissue in $S$. tuberosum microtuber discs cultured in vitro (Takahashi et al. 1994; Table 2). Pruski et al. (2002) pointed out that JA induction of tuberization and microtuber bulking on $S$. tuberosum nodal cuttings was most pronounced under tuberization-inhibiting $16 \mathrm{~h}$ photoperiod. As can be seen different studies indicated that JA and its derivatives stimulated microtuber formation (Hamberg and Gardner 1992; Fig. 3) not only in potato, but also in $D$. rotundata (Jasik and Mantell 2000), D. cayenensis (Ovono et al. 2007) and Pterostylis sanguinea (Debeljak et al. 2002), although a number of studies indicated that JA was not directly involved in process of tuberization in Solanum spp. (Helder et al. 1993; Jackson and Willmitzer 1994; Jackson 1999). This process is also controlled by light, temperature and GA (Lin et al. 2013). It suggests that tuberization is indirectly controlled by JAs through crosstalk with GA signaling (Koda 1997; Wasternack and Hause 2013; Siddiqi and Husen
2019). However, increased accumulation of JA in pretuberous roots of Manihot esculenta planted in the field inhibited tuberous root formation. Those inconsistencies might be due to the differences between potato (i.e., stem tuber) and cassava (i.e., root tuber) and contrasting JAs impact on the cell processes in tissues that differ e.g. in sensitivity to this phytohormone and endogenous level of other PGRs (Utsumi et al. 2020), e.g. cytokinins which were reported to antagonize the JAs effect on $S$. tuberosum microtuber growth after induction. Furthermore JAs effect on microtuber formation is also maturity-specific. The late maturing cultivar may have lower response to JAs (Sarkar et al. 2006).

Commercially grown cultivars are also propagated by other vegetative tissue, such as bulbs. Conventionally bulbs are produced from scales since a long period of time. Micropropagation is similar to the scaling, although under in vitro conditions small scale-explants are used and excised scales from the new bulblets can be used as initial material thus propagation cycles can be performed few times per year (Askari et al. 2018). It was shown that increased JAs level occurs also in bulb forming plants suggesting that this phytohormone is involved in the formation of storage organs other than tubers. JAs plays role in the formation and enlargement of bulblets on N. triandus (Santos and Salema 2000), A. sativum (Bekheet 2006), Allium victorialis (Park et al. 2004) shoot explants placed on MS medium, and A. sativum basal plates transferred onto B5 medium (Ravnikar et al. 1993) (Table 2; Fig. 3). For A. sativum and Narcissus papyraceus it was also noted that JA and MeJA, respectively, stimulated bulblet formation and increased number and weight of bulblets in combination with NAA (Kim et al. 2003; Hosseini et al. 2013), although in N. papyraceus MeJA showed an inhibitory effect on a size of bulblets (Hosseini et al. 2013). Interestingly JA combined with cytokinin 2-iP stimulated bulblets production and its growth in Hyacinthus orientalis (Doğan et al. 2020), although Saniewski and Puchalski (1987) reported that $0.5 \%$ MeJA inhibited benzyladenine-induced bulblet formation in Muscari armeniacum and in lower concentration $(0.1 \%$ and $0.2 \%)$ MeJA delayed development and growth of the bulblets. MeJA decreased bulblet number also in Tulipa gesneriana, although in one of the four studied cultivars (P14) MeJA combined with $500 \mu \mathrm{M}$ Arg increased number of bulblets, their size and weight (Podwyszyńska et al. 2015).

\section{Development of gametophyte and sporophyte}

JA may be involved in alternation of generations in ferns by activating the ontogenesis phases. The JA effect on the growth of gametophyte is age-dependent. JA at $0.1-1.0 \mu \mathrm{M}$ promoted early Platycerium bifurcatum gametophyte development and its transition from a filamentous to a spatulate growth. In turn, after 40 days of culture JA inhibited growth 
of the gametophyte of this species. Authors proposed that maturation of the gametophytes leads to differences in response to JA (Camloh et al. 1996, 2001). In protoplast culture of a sporophyte $0.01 \mu \mathrm{M}$ JA stimulated initial divisions of the cells (Camloh et al. 1996). JA, especially in concentration of $10 \mu \mathrm{M}$, promoted rhizoids and adventitious shoots development on leaves of this species. Stimulatory effect on rhizoid development was observed even in the presence of $100 \mu \mathrm{M} \mathrm{JA}$ (Camloh et al. 1999). Exogenous JA activated growth of the gametophyte and the further sporophytes development on the thallus surface of Anemia tomentosa. It was also observed that JA was able to remain in the gametophyte stage even when sporophytes were already developed (Castilho et al. 2018). However, in horsetail Equisetum arvense JA inhibited growth of gametophytic and sporophytic tissues and also suppressed initiation of sporophytic shoots in vitro (Kuriyama et al. 1993).

\section{JAs as a stimulator of secondary metabolism}

JAs have been widely used as elicitors to induce secondary metabolite production in a variety of plant in vitro cultures. Increased secondary metabolites accumulation was often associated with decreased explants growth. Treatment of Calendula officinalis hairy roots with JA led to slightly decreased growth of the explants, but stimulated secretion of oleanolic acid glycosides into the medium (Alsoufi et al. 2019). Similar correlation was reported for $C$. asiatica. MeJA inhibited shoot, callus and cell suspension culture growth with simultaneous stimulation of asiaticoside (in shoot and callus culture) and asiatic acid (callus culture) biosynthesis (Krishnan et al. 2019). However treatment of adventitious roots of Ajuga bracteosa with NAA and MeJA led to increased maximum dry biomass formation and enhanced total phenolic content (Saeed et al. 2017). Similar results were obtained for Castilleja tenuiflora thirty-dayold in vitro plants elicited by foliar spraying with MeJA (Rubio-Rodríguez et al. 2021). Effect of jasmonates, as for all growth regulators, strictly depends on the used concentration. Treatment of Vitis vinifera with MeJA showed that $100 \mu \mathrm{M}$ and $50 \mu \mathrm{M}$ concentrations enhanced and lowered hairy roots biomass and secretion of resveratrol into the culture medium, respectively (Hoseinpanahi et al. 2020). The wider examples of the JAs usage for elicitation under in vitro conditions can be found in other reviews (Giri and Zaheer 2016; Singh and Dwivedi 2018; Ho et al. 2020).

\section{JAs under stress conditions}

A few studies are available on the effect of JAs on in vitro cultivated plant tissue subjected to stress conditions. Significantly more observations and conclusions were made and reached in pots and fields experiments with foliar application of JAs, e.g. under salinity stress (Manan et al. 2016; Taheri et al. 2020), drought stress (Sadeghipour 2018; Tayyab et al. 2020), heavy metal stress (Ahmad et al. 2017; Ali et al. 2018), heat stress (Lee et al. 2019), cold stress (Connolly and Orrock 2018; Ghanbari et al. 2018) and under biotic stress (Burdziej et al. 2021). Under in vitro conditions JAs were studied under drought, salt and cold stress conditions (Table 3). To simulate drought stress in plants mostly a high molecular weight polyethylene glycol (PEG) has been used as a non-penetrating osmotic agent which lowers the water potential of the medium (Bressan et al. 1981). Improved explants growth under water stress in response to MeJA and JA was reported for M. acuminata and Fragaria $\times$ ananassa (Mahmood et al. 2012; Yosefi et al. 2020). Protective role of JAs might be correlated with a mitigation of oxidative stress by increased activity of POD and SOD enzymes (Yosefi et al. 2020), although contradictory effects of JAs in significantly higher concentration $(200 \mu \mathrm{M})$ were obtained for Verbascum nudicuale seedlings (Ghasemlou et al. 2019). Induced activity of antioxidant enzymes was also observed in T. aestivum under water stress in presence of a low MeJA concentrations $(0.25-2.5 \mu \mathrm{M})$ with simultaneous increase in the level of $\mathrm{H}_{2} \mathrm{O}_{2}$ (Ma et al. 2015), which suggests that JAs might also play role during induction of the oxidative stress. JAs also decreased proline accumulation in B. napus and Saccharum species under water stress. Increased proline level might indicate high stress level or high stress responsivity (Huguet-Robert et al. 2003; Nieves et al. 2001). Bandurska et al. (2003) indicated that exogenous JA increased endogenous level of ABA in Hordeum vulgare and $H$. spontaneum plantlets. $\mathrm{ABA}$ is the principal mediator in physiological outcome of drought avoidance, tolerance and resistance. JA and $\mathrm{ABA}$ seem to share common targets in a signaling pathway related to drought (de Ollas and Dodd 2016). The linkage of these two phytohormones was also indicated in a cold stress (Wang et al. 2016). In Malus $\times$ domestica cultivated in $8{ }^{\circ} \mathrm{C}$ MeJA improved callus growth and increased expression level of the genes involved in cold-signal response (Wang et al. 2019). Encapsulated shoot tips of Taraxacum pieninicum in a calcium alginate matrix showed growth inhibition during cold-storage in the presence of JA, although JA limited proline accumulation and oxidative stress by decreased lipid peroxidation (Kamińska et al. 2018). Application of JAs improved explants condition also under salinity stress, e.g. JAs stimulated growth of the G. $\max$ and S. tuberosum explants (Yoon et al. 2009; Efimova et al. 2019) and 


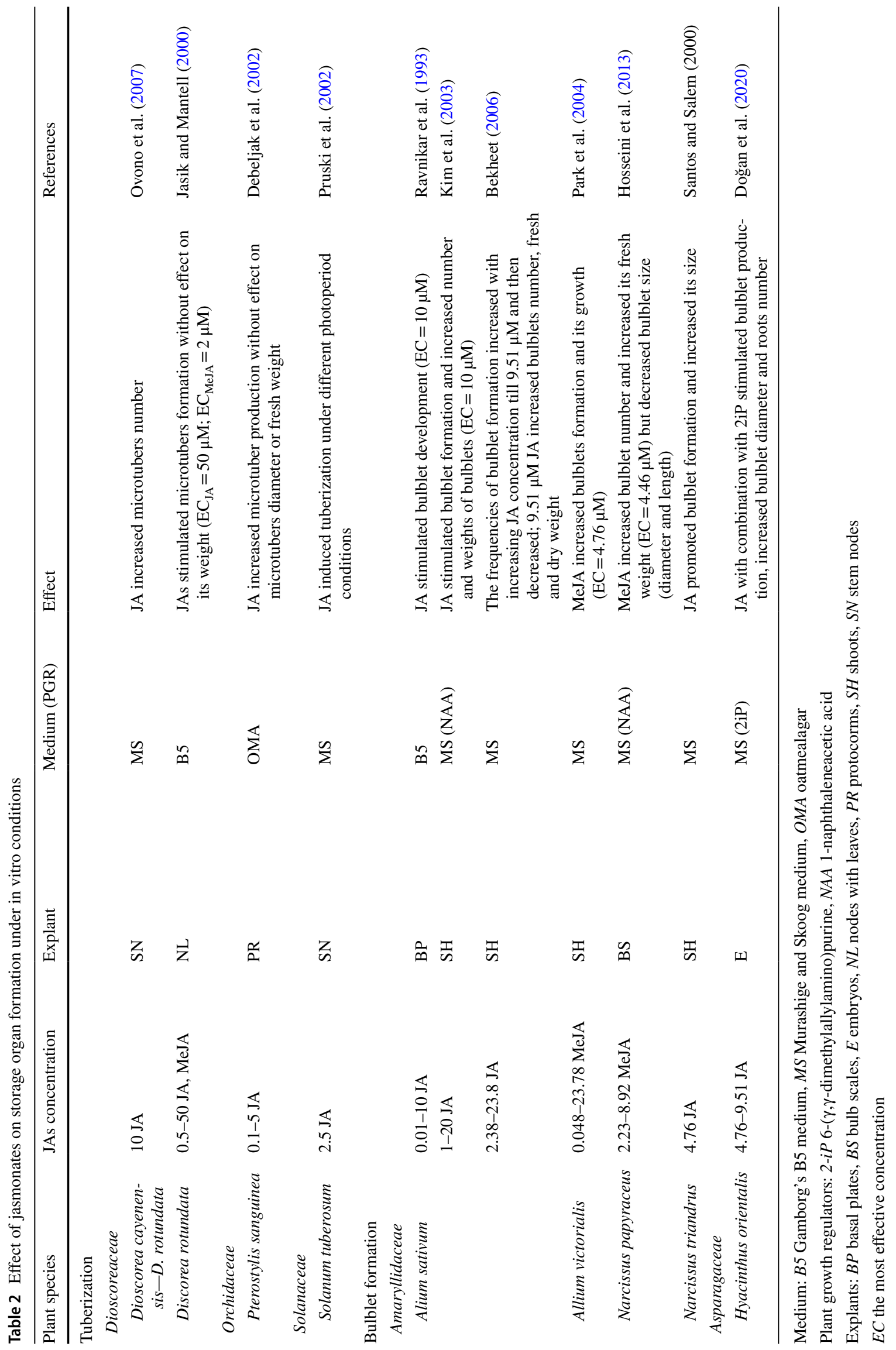


Table 3 Effect of jasmonates on explants conditions under abiotic stress

\begin{tabular}{|c|c|c|c|c|c|c|}
\hline Plant species & Jas concentration & \multicolumn{2}{|c|}{ Explant } & $\begin{array}{l}\text { Stress condi- } \\
\text { tions }\end{array}$ & Effect & References \\
\hline \multicolumn{7}{|l|}{ Water stress } \\
\hline \multicolumn{7}{|l|}{ Brassicaceae } \\
\hline Brassica napus & $50-600 \mu \mathrm{M}$ MeJA & LD & & $\begin{array}{l}178- \\
350 \mathrm{~g} \cdot \mathrm{L}^{-1} \\
\quad \mathrm{PEG}\end{array}$ & MeJA decreased Pro accumulation & Huguet-Robert et al. (2003) \\
\hline \multicolumn{7}{|l|}{ Musaceae } \\
\hline Musa acuminata & 5-160 $\mu \mathrm{M}$ MeJA & ST & & $30 \mathrm{~g} \cdot \mathrm{L}^{-1} \mathrm{PEG}$ & $\begin{array}{l}\text { MeJA above } 5 \mu \mathrm{M} \text { increased proliferation } \\
\text { rate and vigour of shoots, FW, relative } \\
\text { water and Pro content }\end{array}$ & Mahmood et al. (2012) \\
\hline \multicolumn{7}{|l|}{ Poaceae } \\
\hline $\begin{array}{l}\text { Hordeum vulgare } \\
\text { Hordeum spontaneum }\end{array}$ & $5-15 \mu \mathrm{M} \mathrm{JA}$ & PL & & $\begin{array}{l}-1.5 \mathrm{MPa} \\
\text { PEG }\end{array}$ & $\begin{array}{l}\text { JA increased ABA but decreased spermi- } \\
\text { dine content }\end{array}$ & Bandurska et al. (2003) \\
\hline Saccharum sp. hybrid & $4.7 \mu \mathrm{M} \mathrm{JA}$ & ESE & & $\begin{array}{l}0.5 \mathrm{M} \\
\text { sucrose, } \\
\text { silicagel }\end{array}$ & $\begin{array}{l}\text { JA decreased embryos survival, soluble } \\
\text { proteins and free Pro content, increased } \\
\text { starch, total phenolics and polyamines } \\
\text { content }\end{array}$ & Nieves et al. (2001) \\
\hline Triticum aestivum & $0.25-2.5 \mu \mathrm{M}$ MeJA & $\mathrm{C}$ & & $\begin{array}{l}-1.25 \mathrm{MPa} \\
\text { PEG }\end{array}$ & $\begin{array}{l}\text { MeJA increased LOX activity, endogenous } \\
\text { JA and } \mathrm{H}_{2} \mathrm{O}_{2} \text { content, induced antioxidant } \\
\text { enzymes, decreased MDA level and } \\
\text { improved cell viability }\end{array}$ & Ma et al. (2015) \\
\hline \multicolumn{7}{|l|}{ Rosaceae } \\
\hline Fragaria $\times$ ananassa & $10-50 \mu \mathrm{M} J A$ & $\mathrm{HC}$ & & $5-7 \%$ PEG & $\begin{array}{l}\text { JA improved plantlets growth, increased } \\
\text { Chl and carotenoids content, enhanced } \\
\text { activity of POD and SOD enzyme }\end{array}$ & Yosefi et al. (2020) \\
\hline \multicolumn{7}{|l|}{ Scrophulariaceae } \\
\hline Verbascum nudicuale & $200 \mu \mathrm{M}$ MeJA & SD & & $\begin{array}{l}-0.3 \text { and - } \\
0.6 \mathrm{Mpa} \\
\text { PEG }\end{array}$ & $\begin{array}{l}\text { MeJA decreased shoot FW and DW, pho- } \\
\text { tosynthetic pigments contents, increased } \\
\text { total phenol, flavonoid, } \mathrm{H}_{2} \mathrm{O}_{2} \text { and MDA } \\
\text { content, decreased SOD and PPO activ- } \\
\text { ity, increased POD activity }\end{array}$ & Ghasemlou et al. (2019) \\
\hline \multicolumn{7}{|l|}{ Cold stress } \\
\hline \multicolumn{7}{|l|}{ Asteraceae } \\
\hline Taraxacum pieninicum & 24-96 $\mu \mathrm{M}$ JA & ST & $4^{\circ} \mathrm{C}$ & & $\begin{array}{l}\text { JA inhibited explants growth, reduced } \\
\text { accumulation of Pro and TBARS }\end{array}$ & Kamińska et al. (2018) \\
\hline \multicolumn{7}{|l|}{ Rosaceae } \\
\hline Malus $\times$ domestica & $10-1000 \mu \mathrm{M}$ MeJA & $\mathrm{C}$ & $8^{\circ} \mathrm{C}$ & & $\begin{array}{l}\text { MeJA improved calli growth and increased } \\
\text { expression level of the cold-signal } \\
\text { response genes }\end{array}$ & Wang et al. (2019) \\
\hline \multicolumn{7}{|l|}{ Salt stress } \\
\hline \multicolumn{7}{|l|}{ Fabaceae } \\
\hline Glycine $\max$ & $20 \mu \mathrm{M}$ MeJA & SD & & $60 \mathrm{mM} \mathrm{NaCl}$ & $\begin{array}{l}\text { MeJA alleviated the detrimental effect of } \\
\text { salt stress (growth parameters, Chl and } \\
\text { Pro content, photosynthesis and transpi- } \\
\text { ration rate) }\end{array}$ & Yoon et al. (2009) \\
\hline \multicolumn{7}{|l|}{ Solanaceae } \\
\hline Solanum melongena & 10-20 $\mu \mathrm{M}$ JA & $\mathrm{E}$ & & $100 \mathrm{mM} \mathrm{NaCl}$ & $\begin{array}{l}\text { Pretreatment with } 10 \mu \mathrm{M} \text { JA reduced salt } \\
\text { stress affecting embryos development }\end{array}$ & Manar et al. (2013) \\
\hline Solanum tuberosum & $0.001-10 \mu \mathrm{M} \mathrm{JA}$ & PL & & $100 \mathrm{mM} \mathrm{NaCl}$ & $\begin{array}{l}\text { JA stimulated stem growth, number of } \\
\text { tiers and leaves, FW, increased Chl and } \\
\text { carotenoids content }\end{array}$ & Efimova et al. (2019) \\
\hline
\end{tabular}

Explants: $C$ callus, $E$ embryos, $E S E$ encapsulated somatic embryos, $H C$ herbaceous cuttings, $L D$ leaf discs, $P L$ plantlets, $S D$ seedlings, $S T$ shoot tips

$C h l$ chlorophyll, $D W$ dry weight, $F W$ fresh weight, $L O X$ lipoxygenase, $M D A$ malondialdehyde, $P E G$ polyethylene glycol, $P O D$ peroxidase, $P P O$ polyphenol oxidase, Pro proline, $S O D$ superoxide dismutase, TBARS thiobarbituric acid reactive substances 
development of S. melongena embryos (Manar et al. 2013) treated with 60-100 mM NaCl (Table 3). At molecular level it was reported that JA-inducible salt stress related genes were not activated in presence of ABA in $O$. sativa roots, although some evidence of a crosstalk between these phytohormones for regulating salt stress was proposed (Ryu and Cho 2015).

\section{Conclusions}

Jasmonates can differentially affect explants growth under optimal and stress conditions. More detailed works are needed to determine what mechanisms decide about physiological effect of JAs. JA is best studied as an elicitor and undoubtedly plays an important role in a secondary metabolite biosynthesis. The detailed role of JAs in a whole plant or explants growth is still unknown. JAs are often described as a growth retardant during defense related to biotic stresses, however they have also stimulatory effect on explants growth, especially microtubers and bulblets. The crosstalks between JAs and other phytohormone (mainly cytokinins, auxins and gibberellins) seems to be crucial for shoot proliferation, rooting and embryogenesis efficiency of different species. Particularly interaction linking JAs responses with gibberellins signaling pathway is a key factor determining explant growth and tuberization process. Knowledge about the mechanism of JA action in explants will provide useful information, especially important for species with problematic propagation and microprapagation system.

\section{Declarations}

Conflict of interest The authors declare that they have no relevant conflict of interest.

Open Access This article is licensed under a Creative Commons Attribution 4.0 International License, which permits use, sharing, adaptation, distribution and reproduction in any medium or format, as long as you give appropriate credit to the original author(s) and the source, provide a link to the Creative Commons licence, and indicate if changes were made. The images or other third party material in this article are included in the article's Creative Commons licence, unless indicated otherwise in a credit line to the material. If material is not included in the article's Creative Commons licence and your intended use is not permitted by statutory regulation or exceeds the permitted use, you will need to obtain permission directly from the copyright holder. To view a copy of this licence, visit http://creativecommons.org/licenses/by/4.0/.

\section{References}

Abdelsalam A, Chowdhury K, El-Bakry A (2018) Efficient adventitious morphogenesis from in vitro cultures of the medicinal plant Cymbopogon schoenanthus. Plant Tissue Cult Biotechnol 28:147-160. https://doi.org/10.3329/ptcb.v28i2.39674
Achard P, Gusti A, Cheminant S, Alioua M, Dhondt S, Coppens F, Beemster GTS, Genschik P (2009) Gibberellin signaling controls cell proliferation rate in Arabidopsis. Curr Biol 19:1188-1193. https://doi.org/10.1016/j.cub.2009.05.059

Adams E, Turner J (2010) COI1, a jasmonate receptor, is involved in ethylene-induced inhibition of Arabidopsis root growth in the light. J Exp Bot 61:4373-4386. https://doi.org/10.1093/jxb/ erq240

Ahmad P, Alyemeni MN, Wijaya L, Alam P, Ahanger MA, Alamri SA (2017) Jasmonic acid alleviates negative impacts of cadmium stress by modifying osmolytes and antioxidants in faba bean (Vicia faba L.). Arch Agron Soil Sci 63:1889-1899. https://doi. org/10.1080/03650340.2017.1313406

Ahmadi B, Shariatpanahi ME, Teixeira da Silva JA (2014) Efficient induction of microspore embryogenesis using abscisic acid, jasmonic acid and salicylic acid in Brassica napus L. Plant Cell Tiss Organ Cult 116:343-351. https://doi.org/10.1007/ s11240-013-0408-x

Alam P, Albalawi TH (2020) In vitro alteration of artemisinin biosynthesis in Artemisia annиa $\mathrm{L}$ during treatment with methyl jasmonate. Trop J Pharm Res 19:33-37. https://doi.org/10.4314/ tjpr.v19i1.5

Ali MB, Yu KW, Hahn EJ, Paek KY (2006) Methyl jasmonate and salicylic acid elicitation induces ginsenosides accumulation, enzymatic and non-enzymatic antioxidant in suspension culture Panax ginseng roots in bioreactors. Plant Cell Rep 6:613-620. https://doi.org/10.1007/s00299-005-0065-6

Ali E, Hussain N, Shamsi IH, Jabeen Z, Siddiqui MH, Jiang LX (2018) Role of jasmonic acid in improving tolerance of rapeseed (Brassica napus L.) to Cd toxicity. J Zhejiang Univ Sci B 19:130-146. https://doi.org/10.1631/jzus.B1700191

Almagro L, Ros LVG, Belchi-Navarro S, Bru R, Barcelo AR, Pedreno MA (2009) Class III peroxidases in plant defence reactions. J Exp Bot 60:377-390. https://doi.org/10.1093/jxb/ern277

Alsoufi ASM, Pączkowski C, Szakiel A, Długosz M (2019) Effect of jasmonic acid and chitosan on triterpenoid production in Calendula officinalis hairy root culture. Phytochem Lett 31:5-11. https://doi.org/10.1016/j.phytol.2019.02.030

Al-Zuhairi EMA, Ghanm NS (2017) Effect of jasmonic acid (JA) and glutamine on callus induction of Madagascar periwinkle plant (Catharanthus roseus L. cv. Nirvana Pink Blush) by in vitro culture. Int J Curr Microbiol App Sci 6(5):1415-1422. https://doi. org/10.20546/ijcmas.2017.605.154

Askari N, Visser RGF, De Klerk GJ (2018) Growth of lily bulblets in vitro, a review. Int J Hort Sci Technol 5:133-143. https://doi.org/ 10.22059/IJHST.2018.268870.263

Attaran E, Major IT, Cruz JA, Rosa BA, Koo AJ, Chen J, Kramer DM, He SY, Howe GA (2014) Temporal dynamics of growth and photosynthesis suppression in response to jasmonate signaling. Plant Physiol 165:1302-1314. https://doi.org/10.1104/pp.114.239004

Avalbaev A, Yuldashev R, Fedorova K, Somov K, Vysotskaya L, Allagulova C, Shakirova F (2016) Exogenous methyl jasmonate regulates cytokinin content by modulating cytokinin oxidase activity in wheat seedlings under salinity. J Plant Physiol 191:101-110. https://doi.org/10.1016/j.jplph.2015.11.013

Bandurska H, Stroiński A, Kubiś J (2003) The effect of jasmonic acid on the accumulation of ABA, proline and spermidine and its influence on membrane injury under water deficit in two barley genotypes. Acta Physiol Plant 25:279-285. https://doi.org/10. 1007/s11738-003-0009-0

Bassuner BM, Lam R, Lukowitz W, Yeung EC (2007) Auxin and root initiation in somatic embryos of Arabidopsis. Plant Cell Rep 26:1-11. https://doi.org/10.1007/s00299-006-0207-5

Bekheet SA (2006) A synthetic seed method through encapsulation of in vitro proliferated bulblets of garlic (Allium sativum L.). Arab J Biotech 9:415-426 
Betti C, Rovere FD, Ronzan M, Fattorini L (2019) EIN2 and COI1 control the antagonism between ethylene and jasmonate in adventitious rooting of Arabidopsis thaliana thin cell layers. Plant Cell Tiss Organ Cult 138:41-51. https://doi.org/10.1007/ s11240-019-01601-x

Białecka B, Kępczyński J (2003) Endogenous ethylene and reversing methyl jasmonate inhibition of Amaranthus caudatus seed germination by benzyladenine or gibberellin. Plant Growth Regul 41:7-12. https://doi.org/10.1023/A:1027314213064

Biondi S, Scaramagli S, Capitani F, Altamura MM, Torrigiani P (2001) Methyl jasmonates upregulates biosynthetic gene expression, oxidation and conjugation of polyamines, and inhibits shoot formation in tobacco thin layers. J Exp Bot 52:231-242. https://doi.org/10.1093/jexbot/52.355.231

Blázquez S, Piqueras A, Serna MD, Casas JL, Fernández JA (2004) Somatic embryogenesis in saffron: optimization through temporary immersion and polyamine metabolism. Acta Hort 650:269-276. https://doi.org/10.17660/ActaHortic.2004.650. 30

Bressan RA, Hasegawa PM, Handa AK (1981) Resistance of cultures higher plant cells to polyethylene glycol-induced water stress. Plant Sci Lett 21:23-30. https://doi.org/10.1016/0304-4211(81) 90065-1

Bulgakov VP, Tchernoded GK, Veselova MV, Fedoreyev SA, Muzarok TI, Zhuravlev YN (2011) Catechin production in cultured cells of Taxus cuspidata and Taxus baccata. Biotechnol Lett 33:18791883. https://doi.org/10.1007/s10529-011-0632-6

Burdziej A, Bellée A, Bodin E, Fonayet JV, Magnin N, Szakiel A, Richard T, Cluzet S, Corio-Costet MF (2021) Three types of elicitors induce grapevine resistance against downy mildew via common and specific immune responses. J Agric Food Chem 69:1781-1795. https://doi.org/10.1021/acs.jafc.0c06103

Cai XT, Xu P, Zhao PX, Liu R, Yu LH, Xiang CB (2014) Arabidopsis ERF109 mediates cross-talk between jasmonic acid and auxin biosynthesis during lateral root formation. Nat Commun 5:5833. https://doi.org/10.1038/ncomms6833

Camloh M, Ravnikar M, Žel J (1996) Jasmonic acid promotes division of fern protoplasts, elongation of rhizoids and early development of gametophytes. Physiol Plant 97:659-664. https://doi.org/10. 1111/j.1399-3054.1996.tb00529.x

Camloh M, Vilhar B, Žel J, Ravnikar M (1999) Jasmonic acid simulates development of rhizoids and shoots in fern leaf culture. J Plant Physiol 155:798-801. https://doi.org/10.1016/S0176-1617(99) 80100-X

Camloh M, Vilhar B, Žel J (2001) Jasmonic acid induces changes in growth and polypeptide composition of fern gametophytes. Acta Bot Croat 60:149-156

Capitani F, Biondi S, Falasca G, Ziosi V, Balestrazzi A, Carbonera D, Torrigiani P, Altamura MM (2005) Methyl jasmonate disrupts shoot formation in tobacco thin cell layers by over-inducing mitotic activity and cell expansion. Planta 220:507-519. https:// doi.org/10.1007/s00425-004-1362-y

Carra A, Carimi F, Bettoni JC, Pathirana R (2019) Progress and challenges in the application of synthetic seed technology for ex situ germplasm conservation in grapevine (Vitis spp.). In: Faisal M, Alatar A (eds) Synthetic Seeds. Springer, Cham, pp 439-467. https://doi.org/10.1007/978-3-030-24631-0_21

Castilho CVV, Neto JFF, Leitão SG, Barreto CS, Pinto SC, da Silva NCB (2018) Anemia tomentosa var. anthriscifolia in vitro culture: sporophyte development and volatile compound profile of an aromatic fern. Plant Cell Tiss Organ Cult 133:311-323. https://doi.org/10.1007/s11240-018-1383-z

Cenzano A, Vigliocco A, Kraus T, Abdala G (2003) Exogenously applied jasmonic acid induces changes in apical meristem morphology of potato stolons. Ann Bot 91:915-919. https://doi. org/10.1093/aob/mcg098

Chen Q, Sun J, Zhai Q, Zhou W, Qi L, Xu L, Wang B, Chen R, Jiang H, Qi J, Li X, Palme K, Li C (2011) The basic helix-loop-helix transcription factor MYC2 directly represses PLETHORA expression during jasmonate-mediated modulation of the root stem cell niche in Arabidopsis. Plant Cell 23:3335-3352. https://doi.org/ 10.1105/tpc. 111.089870

Chen J, Sonobe K, Ogawa N, Masuda S, Nagatani A, Kobayashi Y, Ohta $\mathrm{H}$ (2013) Inhibition of arabidopsis hypocotyl elongation by jasmonates is enhanced under red light in phytochrome B dependent manner. J Plant Res 126:161-168. https://doi.org/10. 1007/s10265-012-0509-3

Chini A, Boter M, Solano R (2009) Plant oxylipins: COI1/JAZs/MYC2 as the core jasmonic acid-signaling module. FEBS J 276:46824692. https://doi.org/10.1111/j.1742-4658.2009.07194.x

Cho K, Agrawal GK, Shibato J, Jung YH, Kim YK, Nahm BH, Jwa NS, Tamogami S, Han O, Kohda K, Iwahashi H, Rakwal R (2007) Survey of differentially expressed proteins and genes in jasmonic acid treated rice seedling shoot and root at the proteomics and transcriptomics levels. J Proteome Res 6:3581-3603. https://doi. org/10.1021/pr070358v

Connolly BM, Orrock JL (2018) Exogenous application of methyl jasmonates alters Pinus resinosa seedling response to simulated frost. Botany 96:705-710. https://doi.org/10.1139/cjb-2018-0108

Cousins MM, Adelberg JW (2008) Short-term and long-term time course studies of turmeric (Curcuma longa L.) microrhizome development in vitro. Plant Cell Tiss Organ Cult 93:283-293. https://doi.org/10.1007/s11240-008-9375-Z

Creelman RA, Mullet JE (1995) Jasmonic acid distribution and action in plants: regulation during development and response to biotic and abiotic stress. Proc Natl Acad Sci USA 92:4114-4119. https://doi.org/10.1073/pnas.92.10.4114

Creelman RA, Mullet JE (1997) Biosynthesis and action of jasmonates in plants. Annu Rev Plant Physiol Plant Mol Biol 48:355-381. https://doi.org/10.1146/annurev.arplant.48.1.355

Dathe W, Rönsch H, Preiss A, Schade W, Sembdner G, Schreiber K (1981) Endogenous plant hormones of the broad bean, Vicia faba L. (-)-jasmonic acid, a plant growth inhibitor in pericarp. Planta 153:530-535. https://doi.org/10.1007/BF00385537

Debeljak N, Regvar M, Dixon KW, Sivasithamparam K (2002) Induction of tuberisation in vitro with jasmonic acid and sucrose in an Australian terrestrial orchid, Pterostylis sanguinea. Plant Growth Regul 36:253-260. https://doi.org/10.1023/A:1016570319387

De Bruyne L, Höfte M, De Vleesschauwer D (2014) Connecting growth and defense: The emerging roles of brassinosteroids and gibberellins in plant innate immunity. Mol Plant 7:943-959. https://doi.org/10.1093/mp/ssu050

De Klerk GJ (2002) Rooting of microcuttings: theory and practice. In Vitro Cell Dev Biol - Plant 38: 415-422. https://doi.org/https:// doi.org/10.1079/IVP2002335

Dermastia M, Ravnikar M, Vilhar B, Kovač M (1994) Increased level of cytokinin ribosides in jasmonic acid-treated potato (Solanum tuberosum) stem node cultures. Physiol Plant 92:241-246. https://doi.org/10.1111/j.1399-3054.1994.tb05332.x

Doğan S, Çağlar G, Palaz EB (2020) The effect of different applications on in vitro bulb development of an endemic hyacinth plant (Hyacinthus orientalis 1. subsp. chionophyllus Wendelbo) grown in Turkey. Turk J Agric Food Sci Technol 8:1713-1719. https:// doi.org/10.24925/turjaf.v8i8.1713-1719.3473

Dolcet-Sanjuan R, Claveria E (1995) Improved shoot-tip micropropagation of Pistacia vera L. and the beneficial effects of methyl jasmonates. J Am Soc Hort Sci 120:938-942. https://doi.org/10. 21273/JASHS.120.6.938 
Druege U, Hilo A, Pérez-Pérez JM, Klopotek Y, Acosta M, Shahinnia F, Zerche S, Franken P, Hajirezaei MR (2019) Molecular and physiological control of adventitious rooting in cuttings: phytohormone action meets resource allocation. Ann Bot 123:929949. https://doi.org/10.1093/aob/mcy234

Efimova MV, Mukhamatdinova EA, Kovtun IS, Kabil FF, Medvedeva YV, Kuznetsov VV (2019) Jasmonic acid enhances the potato plant resistance to the salt stress in vitro. Dokl Biol Sci 488:149152. https://doi.org/10.1134/S0012496619050077

Fattorini L, Falasca G, Kevers C, Rocca LM, Zadra C, Altamura MM (2009) Adventitious rooting is enhanced by methyl jasmonate in tobacco thin cell layers. Planta 231:155-168. https://doi.org/10. 1007/s00425-009-1035-y

Fattorini L, Veloccia A, Rovere FD, D, Angeli S, Falasca G, Altamura MM, (2017) Indole-3-butyric acid promotes adventitious rooting in Arabidopsis thaliana thin cell layers by conversion into indole-3-acetic acid and stimulation of anthranilate synthase activity. BMC Plant Biol 17:121. https://doi.org/10.1186/ s12870-017-1071-X

Fattorini L, Hause B, Gutierrez L, Veloccia A, Rovere FD, Piacentini D, Falasca G, Altamura MM (2018) Jasmonate promotes auxin-induced adventitious rooting in dark-grown Arabidopsis thaliana seedlings and stem thin cell layers by a cross-talk with ethylene signaling and a modulation of xylogenesis. BMC Plant Biol 18:182. https://doi.org/10.1186/s12870-018-1392-4

Fonseca S, Chini A, Hamberg M, Adie B, Porzel A, Kramell R, Miersch O, Wasternack C, Solano R (2009) (+)-7-iso-JasmonoylL-isoleucine is the endogenous bioactive jasmonate. Nat Chem Biol 5:344-350. https://doi.org/10.1038/nchembio.161

Gaj MD (2001) Direct somatic embryogenesis as a rapid and efficient system for in vitro regeneration of Arabidopsis thaliana. Plant Cell Tiss Organ Cult 64:39-46. https://doi.org/10.1023/A:10106 79614721

Gaspar T, Kevers C, Penel C, Greppin H, Reid DM, Thorpe TA (1996) Plant hormones and plant growth regulators in plant tissue culture. In vitro Cell Dev Biol Plant 32:272-289. https://doi.org/10. 1007/BF02822700

Ghanbari F, Fatahi S, Mohammadi M, Shayan AA (2018) Improvement of tolerance to chilling in watermelon seedlings with methyl jasmonates and methyl salicylate. Thai J Agric Sci 51:1-9

Ghasemlou F, Amiri H, Karamian R, Mirzaie-asi A (2019) Alleviation of the effects of on drought stress Verbascum nudicuale by methyl jasmonate and titanium dioxide nanoparticles. Iran $\mathbf{J}$ Plant Physiol 9:2911-2920. https://doi.org/10.22034/IJPP.2019. 668857

Ghasemi Pirbalouti A, Sajjadi SE, Parang K (2014) A review (research and patents) on jasmonic acid and its derivatives. Arch Pharm Chem Life Sci 347:229-239. https://doi.org/10.1002/ardp.20130 0287

Gheisari M, Miri SM (2017) In vitro callus induction and bulblet regeneration of hyacinth (Hyacinthus orientalis L.). Plant Cell Biotechnol Mol Biol 18:145-155

Giri CC, Zaheer M (2016) Chemical elicitors versus secondary metabolite production in vitro using plant cell, tissue and organ cultures: recent trends and a sky eye view appraisal. Plant Cell Tiss Organ Cult 126:1-18. https://doi.org/10.1007/ s11240-016-0985-6

Goel A, Kaur A, Kumar A (2018) Biochemical and histological changes during in vitro rooting of microcuttings of Bacopa monnieri (L.) Wettst. Acta Physiol Plant 40: 64. https://doi.org/10. 1007/s11738-018-2641-8

Gumerova EA, Akulov AN, Rumyantseva NI (2015) Effect of methyl jasmonate on growth characteristics and accumulation of phenolic compounds in suspension culture of tartary buckwheat. Russ J Plant Physiol 62:195-203. https://doi.org/10.1134/S1021 443715020077
Guo Q, Yoshida Y, Major IT, Wang K, Sugimoto K, Kapali G, Havko NE, Benning C, Howe GA (2018) JAZ repressors of metabolic defense promote growth and reproductive fitness in Arabidopsis. Proc Natl Acad Sci USA 115:E10748-E10777. https://doi.org/ 10.1073/pnas.1811828115

Gutierrez L, Mongelard G, Floková K, Păcurar DI, Novák O, Staswick P, Kowalczyk M, Păcurar M, Demailly H, Geiss G, Bellini C (2012) Auxin controls Arabidopsis adventitious root initiation by regulating jasmonic acid homeostasis. Plant Cell 24:2515-2527. https://doi.org/10.1105/tpc.112.099119

Hamberg M, Gardner HW (1992) Oxylipin pathway to jasmonates biochemistry and biological significance. Biochim Biophys Acta 1165:1-18. https://doi.org/10.1016/0005-2760(92)90069-8

Hannapel DJ, Sharma P, Lin T, Banerjee AK (2017) The multiple signals that control tuber formation. Plant Physiol 174:845-856. https://doi.org/10.1104/pp.17.00272

Helder H, Miersch O, Vreugdenhil D, Sembdner G (1993) Occurrence of hydroxylated jasmonic acids in leaflets of Solanum demissum plants grown under long- and short-day conditions. Physiol Plant 88:647-653. https://doi.org/10.1111/j.1399-3054.1993.tb01384.x

Hibara K, Isono M, Mimura M, Sentoku N, Kojima M, Sakakibara H, Kitomi Y, Yoshikawa T, Itoh J, Nagato Y (2016) Jasmonate regulates juvenile-to-adult phase transition in rice. Development 143:3407-3416. https://doi.org/10.1242/dev.138602

Ho TT, Murthy HN, Park SY (2020) Methyl jasmonate induced oxidative stress and accumulation of secondary metabolites in plant cell and organ cultures. Int J Mol Sci 21:716. https://doi.org/10. 3390/ijms20102525

Horstman A, Bemer M, Boutilier K (2017) A transcriptional view on somatic embryogenesis. Regeneration 4:201-216. https://doi.org/ $10.1002 / \mathrm{reg} 2.91$

Hoseinpanahi B, Bahramnejad B, Majdi M, Dastan D, Ashengroph M (2020) The effect of different elicitors on hairy root biomass and resveratrol production in wild Vitis vinifera. J Appl Biotechnol Rep 7:25-31. https://doi.org/10.30491/JABR.2020.105915

Hosseini R, Moradnejad M, Nezami-Alanagh E, Ashrafi S, Golmohammadi FG (2013) Somatic embryogenesis and bulblet production in Narcissus papyraceus cv. Shirazi: effect of plant growth regulators, light intensity, sucrose concentration, methyl jasmonate and anti-gibberellins. Iran J Genet Plant Breed 2:27-34

Hou X, Ding L, Yu H (2013) Crosstalk between GA and JA signaling mediates plant growth and defense. Plant Cell Rep 32:10671074. https://doi.org/10.1007/s00299-013-1423-4

Huguet-Robert V, Sulpice R, Lefort C, Maerskalck V, Emery N, Larher FR (2003) The suppression of osmoinduced proline response of Brassica napus L. var oleifera leaf discs by polyunsaturated fatty acids and methyl-jasmonate. Plant Sci 164:119-127

Hummel GM, Schurr U, Baldwin IT, Walter A (2009) Herbivoreinduced jasmonic acid bursts in leaves of Nicotiana attenuata mediate short-term reductions in root growth. Plant Cell Environ 32:134-143. https://doi.org/10.1111/j.1365-3040.2008.01905.x

Hyde LS, Pellny TK, Freeman J, Michaelson LV, Simister R, McQueen-Mason SJ, Mitchell RAC (2018) Response of cell-wall composition and RNA-seq transcriptome to methyl-jasmonate in Brachypodium distachyon callus. Planta 248:1213-1229. https:// doi.org/10.1007/s00425-018-2968-9

Ishimaru Y, Hayashi K, Suzuki T, Fukaki H, Prusinska J, Meester C, Quareshy M, Egoshi S, Matsuura H, Takahashi K, Kato N, Kombrink E, Napier RM, Hayashi K, Ueda M (2018) Jasmonic acid inhibits auxin-induced lateral rooting independently of the CORONATINE INSENSITIVE1 receptor. Plant Physiol 177:1704-1716. https://doi.org/10.1104/pp.18.00357

Islam MS, Roni MZK, Shimasaki K (2017) Factors affecting bulblet growth of Lilium sp. in vitro and in vivo. Plant Omics J 10:263268. https://doi.org/10.20944/preprints201910.0063.v1 
Jackson SD, Willmitzer L (1994) Jasmonic acid spraying does not induce tuberisation in short-day-requiring potato species kept in non-inducing conditions. Planta 194:155-159. https://doi.org/ 10.1007/BF01101673

Jackson SD (1999) Multiple signalling pathways control tuber induction in potato. Plant Physiol 119:1-8. https://doi.org/10.1104/ pp.119.1.1

Jang G, Chang SH, Um TY, Lee S, Kim JK, Choi YD (2017) Antagonistic interaction between jasmonic acid and cytokinin in xylem development. Sci Rep 7:10212. https://doi.org/10.1038/ s41598-017-10634-1

Jasik J, Mantell SH (2000) Effects of jasmonic acid and its methylester on in vitro microtuberisation of three food yam (Dioscorea) species. Plant Cell Rep 19:863-867. https://doi.org/10.1007/s0029 90000207

Kamińska M, Tretyn A, Trejgell A (2018) Effect of jasmonic acid on cold-storage of Taraxacum pieninicum encapsulated shoot tips. Plant Cell Tiss Organ Cult 135:487-497. https://doi.org/10.1007/ s11240-018-1481-y

Kim EK, Hahn EJ, Murthy HN, Paek KY (2003) High frequency of shoot multiplication and bulblet formation of garlic in liquid cultures. Plant Cell Tiss Organ Cult 73:231-236. https://doi.org/10. 1023/A:1023029302462

Koç İ, Onay A, Özden Çiftçi Y (2014) In vitro regeneration and conservation of lentisk (Pistacia lentiscus L.). Turk J Biol 38:653-663. https://doi.org/10.3906/biy-1401-69

Koda Y (1997) Possible involvement of jasmonates in various morphogenic events. Physiol Plant 100:639-646. https://doi.org/10. 1111/j.1399-3054.1997.tb03070.x

Kondo S, Tsukada N, Niimi Y (2001) Stimulative effect of jasmonic acid on callus formation in apple fruit. J Japan Soc Hort Sci 70:229-231. https://doi.org/10.2503/jjshs.70.229

Kondo S, Motoyama M, Michiyama H, Kim M (2002) Roles of jasmonic acid in the development of sweet cherries as measured from fruit or disc samples. Plant Growth Regul 37:37-44. https:// doi.org/10.1023/A:1020362926829

Krishnan ML, Roy A, Bharadvaja N (2019) Elicitation effect on the production of asiaticoside and asiatic acid in shoot, callus, and cell suspension culture of Centella asiatica. J App Pharm Sci 9:67-74. https://doi.org/10.7324/JAPS.2019.90609

Krzyzanowska J, Czubacka A, Pecio L, Przybys M, Doroszewska T, Stochmal A, Oleszek W (2011) The effects of jasmonic acid and methyl jasmonate on rosmarinic acid production in Mentha $\times$ piperita cell suspension cultures. Plant Cell Tiss Organ Cult 108:73-81. https://doi.org/10.1007/s11240-011-0014-8

Kumlay AM (2016) The effect of jasmonic acid on the micropropagation of potato (Solanum tuberosum L.) under long days conditions. YYU J Agr Sci 26:79-88

Kuriyama A, Kawai F, Kanamori M, Dathe W (1993) Inhibitory effect of jasmonic acid on gametophytic growth, initiation and development of sporophytic shoots in Equisetum arvense. J Plant Physiol 141:694-697. https://doi.org/10.1016/S0176-1617(11)81576-2

Lakehal A, Bellini C (2018) Control of adventitious root formation: insights into synergistic and antagonistic hormonal interactions. Physiol Plant 165:90-100. https://doi.org/10.1111/ppl.12823

Lakehal A, Dob A, Rahneshan Z, Novák O, Escamez S, Alallaq S, Strnad M, Tuominen H, Bellini C (2020) ETHYLENE RESPONSE FACTOR 115 integrates jasmonate and cytokinin signaling machineries to repress adventitious rooting in Arabidopsis. New Phytol 228:1611-1626. https://doi.org/10.1111/ nph.16794

Lee HJ, Lee JH, Lee SG, An S, LeeHS CCK, Kim SK (2019) Foliar application of biostimulants affects physiological responses and improves heat stress tolerance in Kimchi cabbage. Hortic Environ Biotechnol 60:841-851. https://doi.org/10.1007/ s13580-019-00193-x
Liang Z-S, Yang D-F, Liang X, Zhang Y-H, Liu Y, Liu F-H (2012) Roles of reactive oxygen species in methyl-jasmonate and nitric oxide-induced tanshinone production in Salvia mittiorrhiza hairy roots. Plant Cell Rep 31:873-883. https://doi.org/ 10.1007/s00299-011-1208-6

Lin T, Sharma P, Gonzales DH, Viola IL, Hannapel DJ (2013) The impact of the long-distance transport of a BEL1-like messenger RNA on development. Plant Physiol 161:760-772. https://doi. org/10.1104/pp.112.209429

Lingakumar K, Asha A, Vairamathi SP (2014) Comparative effects of auxins, jasmonic acid and salicylic acid on callus initiation and organogenesis in Vigna mungo (L.) Hepper using hypocotyl explant. J Stress Physiol Biochem 10:262-267

Liu H, Carvalhais LC, Kazan K, Schenk PM (2016) Development of marker genes for jasmonic signaling in shoots and roots of wheat. Plant Signal Behav 11:e1176654. https://doi.org/10. 1080/15592324.2016.1176654

Ma C, Wang Z, Sun M, Zhang L, Kong B, Lin T (2015) Hydrogen peroxide acts as a signaling molecule for the methyl jasmonate-induced antioxidant defense in wheat callus to promote enhanced drought tolerance. J Agric Sci 7:99-114. https://doi. org/10.5539/jas.v7n11p99

Machado RAR, Baldwin IT, Erb M (2017) Herbivory-induced jasmonates constrain plant sugar accumulation and growth by antagonizing gibberellin signaling and not by promoting secondary metabolite production. New Phytol 215:803-812. https://doi.org/10.1111/nph.14597

Mahmood M, Bidabadi SS, Ghobadi C, Gray DJ (2012) Effect of methyl jasmonate treatments on alleviation of polyethylene glycol - mediated water stress in banana (Musa acuminata cv. 'Berangan', AAA) shoot tip cultures. Plant Growth Regul 68:161-169. https://doi.org/10.1007/s10725-012-9702-6

Major IT, Yoshida Y, Campos ML, Kapali G, Xin XF, Sugimoto K, Ferreira DO, He SY, Howe GA (2017) Regulation of growthdefense balance by the JASMONATE ZIM-DOMAIN (JAZ)MYC transcriptional module. New Phytol 215:1533-1547. https://doi.org/10.1111/nph.14638

Major IT, Guo Q, Zhai J, Kapali G, Kramer DM, Howe GA (2020) A phytochrome B-independent pathway restricts growth at high levels of jasmonate defense. Plant Physiol 183:733-749. https://doi.org/10.1104/pp.19.01335

Maksymiec W, Krupa Z (2006) The effects of short-term exposition to $\mathrm{Cd}$, excess $\mathrm{Cu}$ ions and jasmonate on oxidative stress appearing in Arabidopsis thaliana. Environ Exp Bot 57:187194. https://doi.org/10.1016/j.envexpbot.2005.05.006

Manan A, Ayyub CM, Pervez MA, Ahmad R (2016) Methyl jasmonates brings about resistance against salinity stressed tomato plants by altering biochemical and physiological processes. Pak J Agri Sci 53: 35-41. https://doi.org/https://doi. org/10.21162/PAKJAS/16.4441

Manar T, Banu G, Fikret Y, Şebnem K, Özlem U, Şebnem E (2013) The effects of JA treatment on the growth and some enzyme activities of eggplant embryos grown In vitro under salt stress conditions. Res J Biotechnol 8:101-106

Mangas S, Bonfill M, Osuna L, Moyano E, Tortoriello J, Cusido RM, Piñol T, Palazón J (2006) The effect of methyl jasmonate on triterpene and sterol metabolisms of Centella asiatica, Ruscus aculeatus and Galphimia glauca cultured plants. Phytochemistry 67:2041-2049. https://doi.org/10.1016/j.phytochem.2006.06.025

Matsuki T, Tazaki H, Fujimori T, Hogetsu T (1992) The influences of jasmonic acid methyl ester on microtubules in potato cells and formation of potato tubers. Biosci Biotech Biochem 56:1329_ 1330. https://doi.org/10.1271/bbb.56.1329

Matter M, Hanafy M, Aly U (2017) Effect of methyl jasmonate and mannitol application on growth and eugenol content in 
callus cultures of carnation. Plant Tiss Cult Biotech 27:227-240. https://doi.org/10.3329/ptcb.v27i2.35028

Miclea I, Suhani A, Zahan M, Bunea A (2020) Effect of jasmonic acid and salicylic acid on growth and biochemical composition of in-vitro-propagated Lavandula angustifolia Mill. Agronomy 10:1722. https://doi.org/10.3390/agronomy 10111722

Mira MM, Wally OSD, Elhiti M, El-Shanshory A, Reddy DS, Hill RD, Stasolla C (2016) Jasmonic acid is a downstream component in the modulation of somatic embryogenesis by Arabidopsis class 2 phytoglobin. J Exp Bot 67:2231-2246. https://doi.org/10.1093/ jxb/erw022

Moharramnejad S, Azam AT, Panahandeh J, Dehghanian Z, Ashraf M (2019) Effect of methyl jasmonate and salicylic acid on in vitro growth, stevioside production, and oxidative defense system in Stevia rebaudiana. Sugar Tech 21:1031-1038. https://doi.org/10. 1007/s12355-019-00727-8

Monzón GC, Pinedo M, Lamattina L, de la Canal L (2012) Sunflower root growth regulation: the role of jasmonic acid and its relation with auxins. Plant Growth Regul 66:129-136. https://doi.org/10. 1007/s10725-011-9636-4

Moubayidin L, Di Mambro R, Sabatini S (2009) Cytokinin-auxin crosstalk. Trends Plant Sci 14:557-562. https://doi.org/10.1016/j.tplan ts. 2009.06 .010

Napoleao TA, Soares G, Vital CE, Bastos C, Castro R, Loureiro ME, Giordano A (2017) Methyl jasmonate and salicylic acid are able to modify cell wall but only salicylic acid alters biomass digestibility in the model grass Brachypodium distachyon. Plant Sci 263:46-54. https://doi.org/10.1016/j.plantsci.2017.06.014

Nguyen HT, To HTM, Lebrun M, Bellafiore S, Champion A (2019a) Jasmonates - The master regulator of rice development, adaptation and defense. Plants 8:339. https://doi.org/10.3390/plant s8090339

Nguyen KV, Pongkitwitoon B, Pathomwichaiwat T, Viboonjun U, Prathanturarug S (2019b) Effects of methyl jasmonate on the growth and triterpenoid production of diploid and tetraploid Centella asiatica (L.) Urb. hairy root cultures. Sci Rep 9:18665. https://doi.org/10.1038/s41598-019-54460-z

Nic-Can GI, Loyola-Vargas VM (2016) The role of the auxins during somatic embryogenesis. In: Loyola-Vargas V, Ochoa-Alejo N (eds) Somatic embryogenesis: Fundamental aspects and applications. Springer, Cham, pp 171-182. https://doi.org/10.1007/ 978-3-319-33705-0_10

Nieves N, Martínez ME, Castillo R, Blanco MA, González-Olmedo JL (2001) Effect of abscisic acid and jasmonic acid on partial desiccation of encapsulated somatic embryos of sugarcane. Plant Cell Tiss Organ Cult 65:15-21. https://doi.org/10.1023/A:10106 99532641

Noir S, Bömer M, Takahashi N, Ishida T, Tsui TL, Balbi V, Shanahan H, Sugimoto K, Devoto A (2013) Jasmonate controls leaf growth by repressing cell proliferation and the onset of endoreduplication while maintaining a potential stand-by mode. Plant Physiol 161:1930-1951. https://doi.org/10.1104/pp.113.214908

de Ollas C, Dodd IC (2016) Physiological impacts of ABA-JA interactions under water-limitation. Plant Mol Biol 91:641-650. https:// doi.org/10.1007/s11103-016-0503-6

Ovono PO, Kevers C, Dommes J (2007) Axillary proliferation and tuberisation of Dioscorea cayenensis $-D$. rotundata complex. Plant Cell Tiss Organ Cult 91:107-114. https://doi.org/10.1007/ s11240-007-9238-Z

Park SY, Ahn JK, Lee WY, Park HC (2004) Effect of methyl jasmonate on in vitro bulblet formation and enlargement from shoot clump of Allium victorialis. Korean J Plant Biotechnol 31:79-82. https://doi.org/10.5010/JPB.2004.31.1.079

Parthier B (1990) Jasmonates-hormonal regulators or stress factors in leaf senescence. J Plant Growth Regul 9:57-63. https://doi.org/ 10.1007/BF02041942
Patil RA, Lenka SK, Normanly J, Walker EL, Roberts SC (2014) Methyl jasmonates respresses growth and affects cell cycle progression in cultured Taxus cells. Plant Cell Rep 33:1479-1492. https://doi.org/10.1007/s00299-014-1632-5

Pauwels L, Morreel K, Witte ED, Lammertyn F, Montagu MV, Boerjan W, Inzé D, Goossens A (2008) Mapping methyl jasmonate-mediated transcriptional reprogramming of metabolism and cell cycle progression in cultured Arabidopsis cells. Proc Narl Acad Sci USA 105:1380-2138. https://doi.org/10.1073/pnas.0711203105

Pérez-Pérez ME, Lemaire SD, Crespo JL (2012) Reactive oxygen species and autophagy in plants and algae. Plant Physiol 160:156164. https://doi.org/10.1104/pp.112.199992

Perrot-Rechenmann C (2010) Cellular responses to auxin: division versus explansion. Cold Spring Harb Perspect Biol 2:a001446. https://doi.org/10.1101/cshperspect.a001446

Phillips GC, Garda M (2019) Plant tissue culture media and practices: an overview. In Vitro Dev Biol Plant 55:242-257. https://doi.org/ 10.1007/s11627-019-09983-5

Podwyszyńska M, Kosson R, Treder J (2015) Polyamines and methyl jasmonate in bulb formation of in vitro propagated tulips. Plant Cell Tiss Organ Cult 123:591-605. https://doi.org/10.1007/ s11240-015-0863-7

Pruski K, Astatkie T, Nowak J (2002) Jasmonate effects on In vitro tuberization and tuber bul king In two potato cultivars (Solanum tuberosum L.) under different media and photoperiod conditions. In Vitro Cell Dev Biol Plant 38:203-209. https://doi.org/10.1079/ IVPIVP2001265

Ravnikar M, Vilhar B, Gogala N (1992) Stimulatory effects of jasmonic acid on potato stem node and protoplast culture. J Plant Growth Regul 11:29-33. https://doi.org/10.1007/BF00193840

Ravnikar M, Žel J, Plaper I, Špacapan A (1993) Jasmonic acid stimulates shoot and bulb formation of garlic in vitro. J Plant Growth Regul 12:73-77. https://doi.org/10.1007/BF00193236

Rayirath UP, Lada RR, Caldwell CD, Asiedu SK, Sibley KJ (2011) Role of ethylene and jasmonic acid on rhizome induction and growth in rhubarb (Rheum rhabarbarum L.). Plant Cell Tiss Organ Cult 105:253-263. https://doi.org/10.1007/s11240-010-9861-y

Reinbothe C, Tewes A, Lehmann J, Parthier B, Reinbothe S (1994) Induction by methyl jasmonate of embryogenesis-related proteins and mRNAs in Nicotinia plumbaginifolia. Plant Sci 104:59-70. https://doi.org/10.1016/0168-9452(94)90191-0

Rohwer CL, Erwin JE (2008) Horticultural applications of jasmonates: a review. J Hortic Sci Biotech 83:283-304. https://doi.org/10. 1080/14620316.2008.11512381

Rubio-Rodríguez E, Vera-Reyes I, Sepúlveda-García EB, RamosValdivia AC, Trejo-Tapia G (2021) Secondary metabolite production and related biosynthetic genes expression in response to methyl jasmonate in Castilleja tenuiflora Benth. in vitro plants. Plant Cell Tiss Organ Cult 144:519-532. https://doi.org/10.1007/ s11240-020-01975-3

Ruduś I, Kępczyński J, Kępczyńska E (2001) The influence of the jasmonates and abscisic acid on callus growth and somatic embryogenesis in Medicago sativa L. tissue culture. Acta Physiol Plant 23:103-107. https://doi.org/10.1007/s11738-001-0029-6

Ruduś I, Kępczyńska E, Kępczyński J (2006) Comparative efficacy of abscisic acid and methyl jasmonates for indirect somatic embryogenesis in Medicago sativa L. Plant Growth Regul 48:1-11. https://doi.org/10.1007/s10725-005-5136-8

Ruduś I, Weiler EW, Kępczyńska E (2009) Do stress-related phytohormones, abscisic acid and jasmonic acid play a role in the regulation of Medicago sativa L. somatic embryogenesis? Plant Growth Regul 59:159-169. https://doi.org/10.1007/s10725-009-9399-3

Ruiz-May E, De-la-Peña C, Galaz-Ávalos RM, Lei Z, Watson BS, Sumner LW, Loyola-Vargas VM (2011) Methyl jasmonate induces ATP biosynthesis deficiency and accumulation of proteins related to secondary metabolism in Catharanthus roseus 
(L.) G. hairy roots. Plant Cell Physiol 52:1401-1421. https://doi. org/10.1093/pcp/pcr086

Ružić D, Vujović T, Cerović R (2013) Effect of jasmonic acid on in vitro multiplication of low vigorous pear and cherry rootstocks. Fruit Growing Res XXIX:106-112

Ryu H, Cho YG (2015) Plant hormones in salt stress tolerance. J Plant Biol 58:147-155. https://doi.org/10.1007/s12374-015-0103-Z

Sadeghipour O (2018) Drought tolerance of cowpea enhanced by exogenous application of methyl jasmonates. Int J Mod Agric 7:51-57

Saeed S, Ali H, Khan T, Kayani W, Khan MA (2017) Impacts of methyl jasmonates and phenyl acetic acid on biomass accumulation and antioxidant potential in adventitious roots of Ajuga bracteosa Wall ex Benth., a high valued endangered medicinal plant. Physiol Mol Biol Plants 23:229-237. https://doi.org/10.1007/ s12298-016-0406-7

Saniewski M, Puchalski J (1987) The effect of methyl jasmonates and abscisic acid on differentiation of benzyladenine-induced bulblets in Muscari bulbs. Biol Plant 29:63-65. https://doi.org/ 10.1007/BF02902319

Santos I, Salema R (2000) Promotion by jasmonic acid of bulb formation in shoot cultures of Narcissus triandrus L. Plant Growth Regul 30:133-138. https://doi.org/10.1023/A:1006381127884

Sarkar D, Pandey SK, Sharma S (2006) Cytokinins antagonize the jasmonates action on the regulation of potato (Solanum tuberosum) tuber formation in vitro. Plant Cell Tiss Organ Cult 87:285. https://doi.org/10.1007/s11240-006-9166-3

Sembdner G, Meyer A, Miersch O, Brückner C (1990) Metabolism of jasmonic acid. In: Pharis RP, Rood SB (eds) Plant growth substances. Springer, Berlin, Heidelberg, pp 374-382. https:// doi.org/10.1007/978-3-642-74545-4_44

Sembdner G, Parthier B (1993) The biochemistry and the physiological and molecular actions of jasmonates. Annu Rec Plant Physiol Plant Mol Biol 44:569-589. https://doi.org/10.1146/annurev.pp. 44.060193 .003033

Sharma M, Laxmi A (2016) Jasmonates: emerging players in controlling temperature stress tolerance. Front Plant Sci 6:1129. https:// doi.org/10.3389/fpls.2015.01129

Shibaoka H (1991) Microtubules and the regulation of cell morphogenesis by plant hormones. In: Lloyd CW (ed) The cytoskeletal basis of plant growth and form. Academic Press, London, pp 159-168

Shimasaki K, Shiraga T, Fukomoto Y (2003) Effect of methyl jasmonate on organogenesis in shoot cultures of epiphytic and terrestrial Cymbidium species. Environ Control Biol 41:179-182. https://doi.org/10.2525/ECB1963.41.179

Siddiqi KS, Husen A (2019) Plant response to jasmonates: current developments and their role in changing environment. Bull Nat Res Cent 43:153. https://doi.org/10.1186/s42269-019-0195-6

Singh A, Dwivedi P (2018) Methyl-jasmonate and salicylic acid as potent elicitors for secondary metabolite production in medicinal plants: a review. J Pharmacogn Phytochem 7:750-757

Sivanandhan G, Rajesh M, Arun M, Jeyaraj M, Dev GK, Arjunan A, Manickavasagam M, Muthuselvam M, Selvaraj N, Ganapathi A (2013) Effect of culture conditions, cytokinins, methyl jasmonate and salicylic acid on the biomass accumulation and production of withanolides in multiple shoot culture of Withania somnifera (L.) Dunal using liquid culture. Acta Physiol Plant 35:715-728. https://doi.org/10.1007/s11738-012-1112-x

Soares AM, Souza TF, Jacinto T, Machado OLT (2010) Effect of methyl jasmonate on antioxidative enzyme activities and on the contents of ROS and $\mathrm{H}_{2} \mathrm{O}_{2}$ in Ricinus communis leaves. Braz J Plant Physiol 22:151-158. https://doi.org/10.1590/S1677-04202 010000300001

Staswick PE, Tiryaki I (2004) The oxylipin signal jasmonic acid is activated by an enzyme that conjugates it to isoleucine in Arabidopsis. Plant Cell 16:2117-2127. https://doi.org/10.1105/tpc. 104.023549
Staswick PE (2009) The tryptophan conjugates of jasmonic and indole3 -acetic acids are endogenous auxin inhibitors. Plant Physiol 150:1310-1321. https://doi.org/10.1104/pp.109.138529

Sultana J, Sultana N, Siddique MNA, Islam AKMA, Hossain MM, Hossain T (2010) In vitro bulb production in Hippeastrum (Hippeastrum hybridum). J Cent Eur Agric 11:469-474. https://doi. org/10.5513/JCEA01/11.4.867

Sun J, Cardoza V, Mitchell DM, Bright L, Oldroyd G, Harris JM (2006) Crosstalk between jasmonic acid, ethylene and Nod factor signaling allows integration of diverse inputs for regulation of nodulation. Plant J 46:961-970. https://doi.org/10.1111/j.1365-313X. 2006.02751.x

Sun J, Xu Y, Ye S, Jiang H, Chen Q, Liu F, Zhou W, Chen R, Li X, Tietz O, Wu X, Cohen JD, Palme K, Li C (2009) Arabidopsis ASAl is important for jasmonate-mediated regulation of auxin biosynthesis and transport during lateral root formation. Plant Cell 21:1495-1511. https://doi.org/10.1105/tpc.108.064303

Świątek A, Lenjou M, van Bockstaele D, Inzé D, van Onckelen $H$ (2002) Differential effect of jasmonic acid and abscisic acid on cell cycle progression in tobacco BY-2 cells. Plant Physiol 128:201-211. https://doi.org/10.1104/pp.010592

Świątek A, Azmi A, Stals H, Inzé D, Van Onckelen H (2004) Jasmonic acid prevents the accumulation of cyclin B1;1 and CDK-B in synchronized tobacco BY-2 cells. FEBS Lett 572:118-122. https://doi.org/10.1016/j.febslet.2004.07.018

Taheri Z, Vatankhah E, Jafarian V (2020) Methyl jasmonates improves physiological and biochemical responses of Anchusa italica under salinity stress. S Afr J Bot 130:375-382. https://doi.org/ 10.1016/j.sajb.2020.01.026

Takahashi K, Fujino K, Kikuta Y, Koda Y (1994) Expansion of potato cells in response to jasmonic acid. Plant Sci 100:3-8. https://doi. org/10.1016/0168-9452(94)90127-9

Tampe PA, Reid DM, Thorpe TA (2001) Jasmonic acid inhibition of in vitro shoot organogenesis in Pinus radiata cotyledons. J Plant Physiol 158:607-611. https://doi.org/10.1078/0176-1617-00317

Tayyab N, Naz R, Yasmin H, Nosheen A, Keyani R, Sajjad M, Hassan MN, Roberts TH (2020) Combined seed and foliar pre-treatments with exogenous methyl jasmonate and salicylic acid mitigate drought-induced stress in maize. PLoS ONE 15(5):e0232269. https://doi.org/10.1371/journal.pone.0232269

Teixeira da Silva JA (2012) Impact of methyl jasmonate on PLB formation of hybrid Cymbidium (Orchidaceae). J Plant Develop $19: 47-52$

Tokuji Y, Mizue Y, Masuda H (1995) Effects of methyl jasmonate and concanavalin $\mathrm{A}$ on embryogenesis and the induction of secondary somatic embryos of carrot. Biosi Biotech Biochem 59:1675-1678. https://doi.org/10.1271/bbb.59.1675

Toro FJ, Martín-Closas L, Pelacho AM (2003) Jasmonates promote cabbage (Brassica oleracea L. var Capitata L.) root and shoot development. In: Abe J (ed) Roots: The dynamic interface between plants and the Earth. Developments in Plant and Soil Sciences, vol 101. Springer, Dordrecht, pp 77-83. https://doi.org/ 10.1007/978-94-017-2923-9_8

Tung P, Hooker TS, Tampe PA, Reid DM, Thorpe TA (1996) Jasmonic acid: effects on growth and development of isolated tomato roots cultured in vitro. Int J Plant Sci 157:713-721. https://doi.org/10. $1086 / 297393$

Ueda J, Kato J (1982) Inhibition of cytokinin-induced plant growth by jasmonic acid and its methyl ester. Physiol Plant 54:249-252. https://doi.org/10.1111/j.1399-3054.1982.tb00255.x

Ueda M, Kaji T, Kozaki W (2020) Recent advances in plant chemical biology of jasmonates. Int J Mol Sci 21:1124. https://doi.org/10. 3390/ijms21031124

Utsumi Y, Tanaka M, Utsumi C, Takahashi S, Matsui A, Fukushima A, Kobayashi M, Sasaki R, Oikawa A, Kusano M, Saito K, Kojima M, Sakakibara H, Sojikul P, Narangajavana J, Seki M (2020) 
Integrative omics approaches revealed a crosstalk among phytohormones during tuberous root development in cassava. Plant Mol Biol (online). https://doi.org/10.1007/s11103-020-01033-8

Wang P, Hu C (1982) In vitro mass tuberization and virus-free seedpotato production in Taiwan. Am Potato J 59:33-37. https://doi. org/10.1007/BF02854881

Wang F, Guo Z, Li H, Wang M, Onac E, Zhou J, Xia X, Shi K, Yu J, Zhou Y (2016) Phytochrome A and B function antagonistically to regulate cold tolerance via abscisic acid-dependent jasmonate signaling. Plant Physiol 170:459-471. https://doi.org/10.1104/ pp. 15.01171

Wang Y, Xu H, Liu W, Wang N, Qu C, Jiang S (2019) Methyl jasmonate enhances apple' cold tolerance through the JAZ-MYC pathway. Plant Cell Tiss Organ Cult 136:75-84. https://doi.org/ 10.1007/s11240-018-1493-7

Wasternack C, Hause B (2013) Jasmonate: biosynthesis, perception, signal tranduction and action in plant stress response, growth and development. An uptade to the 2007 review in Annals of Botany. Ann Bot 111:1021-1058. https://doi.org/10.1093/aob/mct067

Xiao Y, Chen Y, Charnikhova T, Mulder PPJ, Heijmans J, Hoogenboom A, Agalou A, Michel C, Morel JB, Dreni L, Kater MM, Bouwmeester H, Wang M, Zhu Z, Ouwerkerk PBF (2014) $O S J A R 1$ is required for JA-regulated floret opening and anther dehiscence in rice. Plant Mol Biol 86:19-33. https://doi.org/10. 1007/s11103-014-0212-y

Xue R, Zhang B (2007) Increased endogenous methyl jasmonate altered leaf and root development in transgenic soybean plants. J Genet Genomics 34:339-346. https://doi.org/10.1016/S16738527(07)60036-8

Yan Y, Stolz S, Chetelat A, Reymond P, Pagni M, Dubugnon L, Farmer EE (2007) A downstream mediator in the growth repression limb of the jasmonate pathway. Plant Cell 19:2470-2483. https://doi. org/10.1105/tpc. 107.050708

Yan J, Zhang C, Gu M, Bai Z, Zhang W, Qi T, Cheng Z, Peng W, Luo H, Nan F, Wang Z, Xie D (2009) The Arabidopsis CORONATINE INSENSITIVE1 protein is a jasmonate receptor. Plant Cell 21:2220-2236. https://doi.org/10.1105/tpc.109.065730

Yan J, Li S, Gu M, Yao R, Li Y, Chen J, Yang M, Tong J, Xiao L, Nan F, Xie D (2016) Endogenous bioactive jasmonates is composed of a set of (+)-7-iso-JA-amino acid conjugates. Plant Physiol 172:2154-2164. https://doi.org/10.1104/pp.16.00906

Yang X, Zhang X (2010) Regulation of somatic embryogenesis in higher plants. Crit Rev Plant Sci 29:36-57. https://doi.org/10. 1080/07352680903436291

Yang DL, Yao J, Mei CS, Tong XH, Zeng LJ, Li Q, Xiao LT, Sun TP, Li JG, Deng XW, Lee CM, Thomashow MF, Yang Y, He Z, He SY (2012) Plant hormone jasmonate prioritizes defense over growth by interfering with gibberellin signaling cascade. Proc
Natl Acad Sci USA 109:1192-1200. https://doi.org/10.1073/ pnas. 1201616109

Yang J, Duan G, Li C, Liu L, Han G, Zhang Y, Wang C (2019) The crosstalks between jasmonic acid and other plant hormone signaling highlight the involvement of jasmonic acid as a core component in plant response to biotic and abiotic stresses. Front Plant Sci 10:1349. https://doi.org/10.3389/fpls.2019.01349

Yoon JY, Hamayun M, Lee SK, Lee IJ (2009) Methyl jasmonate alleviated salinity stress in soybean. J Crop Sci Biotechnol 12:63-68. https://doi.org/10.1007/s12892-009-0060-5

Yosefi A, Aa M, Javadi T (2020) Jasmonic acid improved in vitro strawberry (Fragaria $\times$ ananassa Duch.) resistance to PEG-induced water stress. Plant Cell Tiss Organ Cult 142:549-558. https://doi. org/10.1007/s11240-020-01880-9

Zare-Hassani E, Motafakkerazad R, Razeghi J, Kosari-Nasab M (2019) The effects of methyl jasmonate and salicylic acid on the production of secondary metabolites in organ culture of Ziziphora persica. Plant Cell Tiss Organ Cult 138:437-444. https://doi.org/ 10.1007/s11240-019-01639-x

Zhai Q, Li CB, Zheng W, Wu X, Zhao J, Zhou G, Jiang H, Sun J, Lou Y, Li C (2007) Phytochrome chromophore deficiency leads to overproduction of jasmonic acid and elevated expression of jasmonate - responsive genes in Arabidopsis. Plant Cell Physiol 48:1061-1071. https://doi.org/10.1093/pcp/pcm076

Zhai Q, Yan C, Li L, Xie D, Li C (2017) Jasmonates. In: Li J, Li C, Steven M, Smith SM (eds) Hormone metabolism and signaling in plants. Academic, New York, pp 243-272. https://doi.org/10. 1016/B978-0-12-811562-6.00007-4

Zhang ZJ, Zhou WJ, Li HZ, Zhang GQ, Subrahmaniyan K, Yu JQ (2006) Effect of jasmonic acid on in vitro explant growth and microtuberization in potato. Biol Plant 50:453-456. https://doi. org/10.1007/s10535-006-0069-2

Zhang Y, Turner JG (2008) Wound-induced endogenous jasmonates stunt plant growth by inhibiting mitosis. PLoS ONE 3:e3699. https://doi.org/10.1371/journal.pone.0003699

Zhang L, Xing D (2008) Methyl jasmonate induces production of reactive oxygen species and alterations in mitochondrial dynamics that precede photosynthetic dysfunction and subsequent cell death. Plant Cell Physiol 49:1092-1111. https://doi.org/10.1093/ $\mathrm{pcp} / \mathrm{pcn} 086$

Zhou W, Lozano-Torres JL, Blilou I, Zhang X, Zhai Q, Smant G, Li C, Scheres B (2019) A jasmonate signaling network activates root stem cells and promotes regeneration. Cell 177:942-956. https:// doi.org/10.1016/j.cell.2019.03.006

Publisher's Note Springer Nature remains neutral with regard to jurisdictional claims in published maps and institutional affiliations. 